\begin{tabular}{l} 
Sharif University of Technology \\
Scientia Iranica \\
SCIENTIA \\
IRAN \\
Thanstions A: Civil Engineering \\
\hline
\end{tabular}

\title{
The effect of different curing temperatures on engineering properties of chemically grouted sands
}

\author{
E. Avci* \\ Department of Civil Engineering, Bursa Technical University, 152 Evler Street No. 2/10, Yıldırım-Bursa, Turkey.
}

Received 3 January 2018; received in revised form 2 May 2018; accepted 22 October 2018

\author{
KEYWORDS \\ Sodium silicate \\ grouts; \\ Curing temperature; \\ Unconfined \\ compressive strength; \\ Permeability; \\ Groutability; \\ Syneresis.
}

\begin{abstract}
In this experimental study, the effect of curing temperature on the engineering properties of sand samples grouted with sodium silicate-glyoxal was investigated. The experiments began with determining gelation times, viscosities, and syneresis percentages of the blends prepared for injection. Thereafter, the injection experiments were carried out at the determined mixing ratios. Grouted specimens were subjected to Unconfined Compressive Strength (UCS) and permeability tests at different curing temperatures $\left(+10^{\circ} \mathrm{C},+20^{\circ} \mathrm{C}\right.$, and $\left.+30^{\circ} \mathrm{C}\right)$ being kept in the curing tank. As the temperature increased, the viscosity values and gelling times decreased, while the syneresis percentages increased. The UCS of the grouted samples decreased with time. This decreasing trend slowed down in the case of the samples kept at $+10^{\circ} \mathrm{C}$ after the 56 th day, while the same was seen in the case of those specimens kept at $+20^{\circ} \mathrm{C}$ and for those kept at $+30^{\circ} \mathrm{C}$ on the 7 th and 28 th days. Further, UCS values decreased with the increasing temperature. The permeability values of the grouted samples decreased with time. This decreasing trend slowed down after the $28 \mathrm{th}$ day. An increase in temperature reduced permeability values.
\end{abstract}

(C) 2020 Sharif University of Technology. All rights reserved.

\section{Introduction}

In geotechnical engineering, many grouting techniques are used. Permeation grouting is the most common one among these. It is defined as the injection of suspensions and/or solution materials into the soil at low pressures. Such materials as suspensions, solutions, and emulsions are utilized for permeation grouting [110]. Chemical grouting materials are the oldest and the most preferred ones in permeation injections. Chemical grouting materials reduce permeability and increase the strength of soils and rocks by gelling in voids and/or cracks of soils and rocks. There are many chemical grouting materials that are different from each other in terms of chemical composition and components

*. Tel.: +902243003741

E-mail address: eyubhanavci@gmail.com

doi: $10.24200 /$ sci.2018.50177.1557 throughout the world. The most commonly used ones include sodium silicates, acrylamides, lignosulfonates, phenoplasts, and aminoplasts [11-14].

Chemical grouts can be well applied to the conditions mentioned below [15]:

- Seepage control in a dam reservoir;

- Decreasing the soil liquefaction;

- Increasing the bearing capacity and decreasing the settlement of soil material beneath the foundations of structures;

- Stabilizing the ground around cutting face and managing the settlement of ground surface while maintaining tunnel opening activities;

- Lifting and erecting the leaning structures and buildings;

- Filling the gaps between rock and tunnel linings.

Preferable grouts among other chemical ones include sodium silicates since they are considered to be 
the least toxic, safe, environmentally compatible, and cost effective. Sodium silicates are prepared through the heat treatment of silicate sand or any form of silicate at $900^{\circ} \mathrm{C}$ with $\mathrm{Na}_{2} \mathrm{CO}_{3}$. After being refined, sodium silicate takes the form of an aqueous/fluid solution. Water is added to this solution at various ratios to obtain the desired concentration [16]. The prepared solution is neutralized by adding a material with acidic character as a reactant and gelled. Over time, syneresis is observed in the gelling solutions. Syneresis is defined as the release of water after reactions or deterioration of the gel structure. Shrinkage is observed in the gel structure when syneresis appears. Strength and permeability tests on sodium silicate grouted sands have been carried out by several researchers [17-24]. In the experimental studies conducted, the effects of curing temperature on the engineering properties of grouted sand were not investigated.

In this experimental study, the engineering properties of sodium silicate-glyoxal grouted sands were investigated at different curing temperatures.

\section{Materials used}

\subsection{Grout properties and chemical reaction}

Sodium silicate $\left(\mathrm{SiO}_{2} \cdot \mathrm{Na}_{2} \mathrm{O}\right)$ can either be found in the form of liquid solution or in powder. The ratio of silica/alkali $(n)$ is mostly utilized in the ranges of 3 to 4 to obtain gels having adhesive characteristics notably suitable for injection. Sodium silicate used in this research is manufactured under the name of EGENat 3203 by Ege Holding in Turkey. Its physicochemical properties are provided in Table 1.
Sodium silicates need neutralizing so that they can be formed into gel. For this purpose, the reactant used in the study was organic glyoxal produced by Across Company. The physico-chemical qualities of glyoxal are presented in Table 1 . In addition, drinkable tap water as the third component was used during the formation of grouts.

Silica is a weak acid, thus making sodium silicate basic. Sodium silicate is precipitated as gel product through neutralization. Firstly, glyoxal $\left(\mathrm{C}_{2} \mathrm{H}_{2} \mathrm{O}_{2}\right)$ is converted to the oxalaldehyde form through acidic medium. Then, a dilute sodium silicate $\left(\mathrm{Na}_{2} \mathrm{SiO}_{3}\right)$ mixed with organic origin oxalaldehyde $\left(\mathrm{C}_{2} \mathrm{H}_{4} \mathrm{O}_{2}\right)$ would lead to the formation of a gel over time based on the chemical concentrations. The reaction scheme is presented in Eqs. (1) and (2) as shown in Box I.

The glyoxal was transformed into oxalaldehyde, acidic derivative, through acidic medium (Eq. (1)). Then, the acidic oxalaldehyde was neutralized with basic sodium silicate, as shown in Eq. (2). Afterwards, the sodium formate $\left(\mathrm{C}_{2} \mathrm{H}_{2} \mathrm{O}_{2} \mathrm{Na}_{2}\right)$ salt and silicic acid $\left(\mathrm{H}_{2} \mathrm{SiO}_{3}\right)$ were derived; however, the silicic acid was observed to be unstable in air atmosphere; for this reason, it turned into silicium dioxide (silica or silicon dioxide) $\left(\mathrm{SiO}_{2}\right)$ by releasing one molecule aqua and the mixture became gelled.

\subsection{Sand}

In this study, the quartzite sand specimens were procured from the bank of Kizllırmak River running to the Black Sea in Turkey. Firstly, the sand used was divided into two subgroups. Each of the subgroups was obtained by being sifted through two sieves on

Table 1. Physico-chemical properties of sodium silicate and glyoxal.

\begin{tabular}{|c|c|c|}
\hline \multirow{10}{*}{ 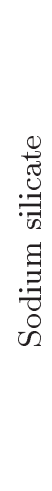 } & Coloring & Colorless, clear liquid \\
\hline & Formulation & $\mathrm{Na}_{2} \mathrm{SiO}_{3}$ \\
\hline & Weight modules $\left(\mathrm{SiO}_{2} / \mathrm{NaO}\right)$ & $3.0-3.3$ \\
\hline & Molecular modules $\left(\mathrm{SiO}_{2} / \mathrm{NaO}\right)$ & $3.1-3.4$ \\
\hline & $\mathrm{Be}^{\prime}\left(20^{\circ} \mathrm{C}\right)$ & $39-41$ \\
\hline & Density $\left(20^{\circ} \mathrm{C}, \mathrm{gr} / \mathrm{cm}^{3}\right)$ & $1.37-1.39$ \\
\hline & $\mathrm{Na}_{2} \mathrm{O}(\%)$ & $8.5-9.5$ \\
\hline & $\mathrm{SiO}_{2}(\%)$ & $26.0-28.0$ \\
\hline & $\mathrm{pH}\left(20^{\circ} \mathrm{C}\right)$ & 11.66 \\
\hline & Viscosity $\left(20^{\circ} \mathrm{C}, \mathrm{cP}\right)$ & $75-150$ \\
\hline \multirow{6}{*}{ 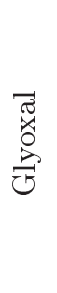 } & Coloring & Clear colorless to yellow liquid \\
\hline & Formulation & $\mathrm{C}_{2} \mathrm{H}_{2} \mathrm{O}_{2}$ \\
\hline & Formula weight (gr/mol) & 58.04 \\
\hline & Density $\left(20^{\circ} \mathrm{C}, \mathrm{gr} / \mathrm{cm}^{3}\right)$ & 1.27 \\
\hline & Acetic acid & $0.25 \%$ max. \\
\hline & $\mathrm{pH}\left(20^{\circ} \mathrm{C}\right)$ & $2.1-2.7$ \\
\hline
\end{tabular}



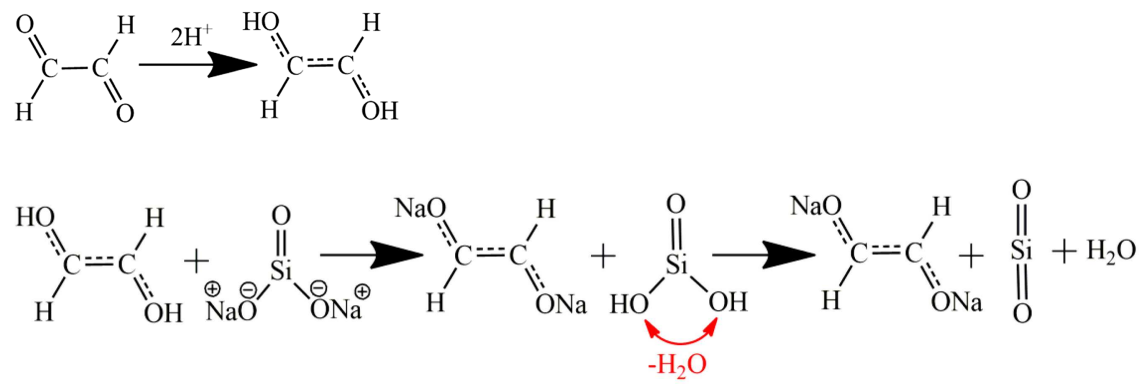

Box I

Table 2. Properties of sand specimens used in experimental studies.

\begin{tabular}{ccccccc}
\hline Sample no. & $\begin{array}{c}\text { Particle size content } \\
(\mathbf{\%})\end{array}$ & $\begin{array}{c}\gamma_{d r y}(\mathbf{m a x}) \\
\mathbf{k N} / \mathbf{m}^{3}\end{array}$ & $\begin{array}{c}\boldsymbol{\gamma}_{\boldsymbol{d r y}}(\mathbf{m i n}) \\
\mathbf{k N} / \mathbf{m}^{3}\end{array}$ & $e_{\max }$ & $\boldsymbol{e}_{\min }$ \\
\cline { 2 - 4 } & Fine & Medium & 15.80 & 12.60 & 1.14 & 0.71 \\
\hline 1 & 100 & 0 & 15.60 & 12.70 & 1.12 & 0.73 \\
2 & 60 & 40 & 15.50 & 12.90 & 1.10 & 0.74 \\
3 & 30 & 70 & 15.40 & 13.00 & 1.08 & 0.75 \\
\hline
\end{tabular}

Note: $\gamma_{d r y}(\max ):$ Maximum dry unit weight; $\gamma_{d r y}(\min )$ : Minimum dry unit weight;

$e_{\max }:$ Maximum void ratio; $e_{\min }$ : Minimum void ratio.

which the coarser fraction of sand particles first passed through a set of upper sieves (no. 10-no. 40) and those retained on No. $40(0.475 \mathrm{~mm})$ sieve were gathered and called as medium sand. Then, the other subgroup was left to pass through a set of lower sieves (no. 40-no. 200). The sand particles to be retained on sieve no. 200 $(0.075 \mathrm{~mm})$ were gathered and named as fine sand [25]. Fine and medium sands were mixed with each other at different percentages by dry mass in an attempt to broaden the range of sand gradations (Table 2). Four diverse gradations were obtained along these lines, and their grain size distributions are presented in Figure 1.

In order to prepare the sand samples for grouting at a relative density of $30 \%$, their specific gravity, maximum dry unit weight, and minimum dry unit weights (Table 2) were also identified in line with ASTM D 854-02 [26], ASTM D 4253-00 [27], and ASTM D 4254-00 [28] standards, respectively.

\subsection{Grouting}

The grouting equipment developed by Mollamahmutoğlu and Avcı [29] was mainly made up of a grout tank involving a propeller and a manometer and, also, specimen molds were characterized by $120 \mathrm{~mm}$ in length and $52 \mathrm{~mm}$ in diameter and other fitting components (Figure 2).

Firstly, the inside surfaces of specimen molds were

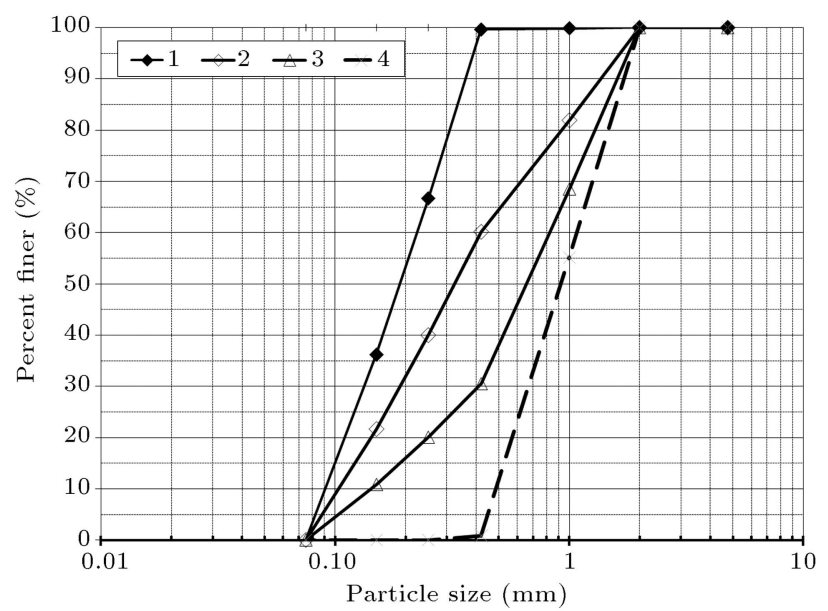

Figure 1. Distribution of the particle size of sand samples.

slightly greased in order to reduce sample disturbance during the course of removal following grouting. A sand layer of about $8 \mathrm{~mm}$ thick coarse was laid out on the bottom of the molds to equally disperse the grout into the sample. Sand was then poured into molds in the form of three equal layers, each of which was compacted by using a wooden dolly to reach the intended density prior to the placement of the next layer. Another coarse sand layer characterized by $8 \mathrm{~mm}$ thickness was also laid out on the top of the molds to avoid the dragging 


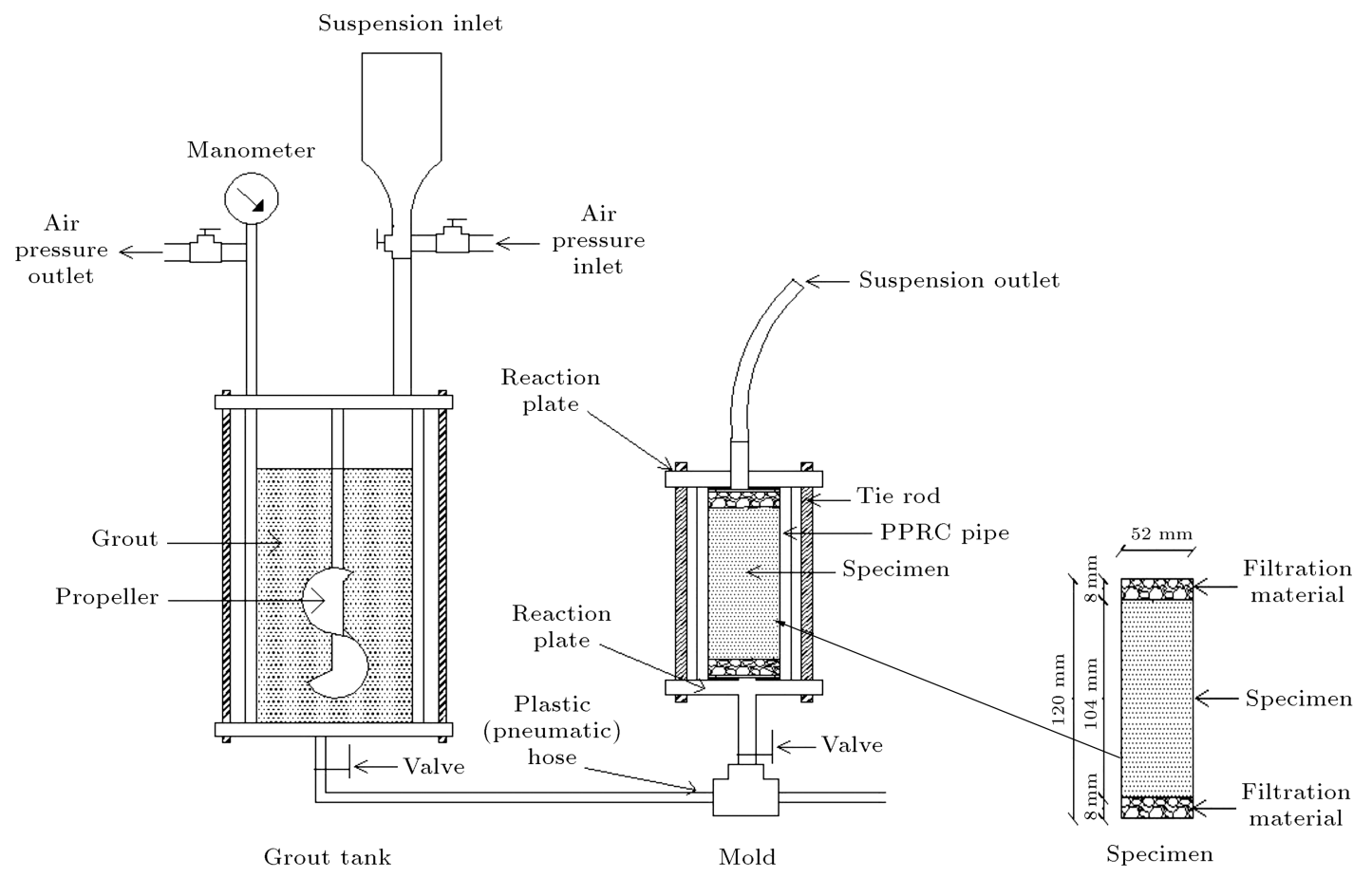

Figure 2. Grouting test equipment.

Table 3. Mixing ratios of grout solutions.

\begin{tabular}{|c|c|c|c|}
\hline Solution no. & $\begin{array}{c}\text { Water } \\
(\%)\end{array}$ & $\begin{array}{c}\text { Sodium silicate } \\
(\%)\end{array}$ & $\begin{array}{c}\text { Glyoxal } \\
(\%)\end{array}$ \\
\hline $\mathrm{C} 1$ & 20 & 70 & 10 \\
\hline $\mathrm{C} 2$ & 30 & 60 & 10 \\
\hline C3 & 40 & 50 & 10 \\
\hline $\mathrm{C} 4$ & 50 & 40 & 10 \\
\hline C5 & 60 & 30 & 10 \\
\hline
\end{tabular}

of particles together with the grout on exit. Following this, the end-plates of the molds were bound together (Figure 2). Finally, the specimens in the molds were saturated with water in order to ensure that no air bubbles could be released from the outlet.

Table 3 shows the quantity of the components forming the sodium silicate-glyoxal grouts for this experimental study.

Initially, amounts of reactant and water, previously determined by means of graduated glass cylinders, were blended entirely in a container by means of a magnetic agitator. The previously determined sodium silicate was then added, and the entire mixture was again blended. The mixture was moved to the injection tank and, then, grouted into the specimen in the molds. Trial and error approach was utilized to determine the grouting pressures for specimens and, accordingly, the permeation limit pressures were determined. An air compressor provided the grout pressure, which was monitored by a manometer mounted on it.

\section{Experimental study}

\subsection{Gel time, viscosity, and syneresis}

The process that lasts until the fluidity of the grouting material is lost and then solidified is called gelling time [30]. The gelling time is defined by Verfel [31] as the time between the moment when the mixture is added to the reaction and the instant when the viscosity value reaches $100 \mathrm{cP}$. The gelling duration was determined at 3 different temperatures $\left(+10^{\circ} \mathrm{C}\right.$, $+20^{\circ} \mathrm{C}$, and $+30^{\circ} \mathrm{C}$ ) and on 5 mixtures. Figure 3 shows

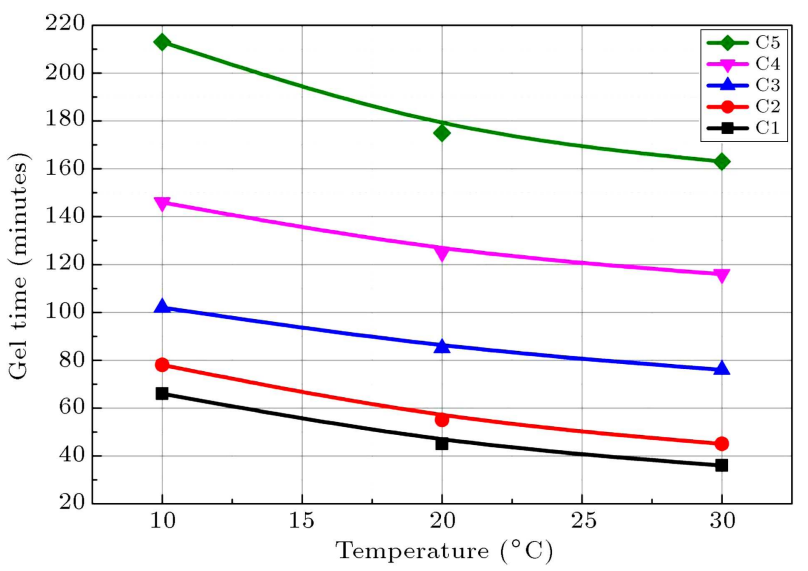

Figure 3. The relationship between gel time and temperature. 


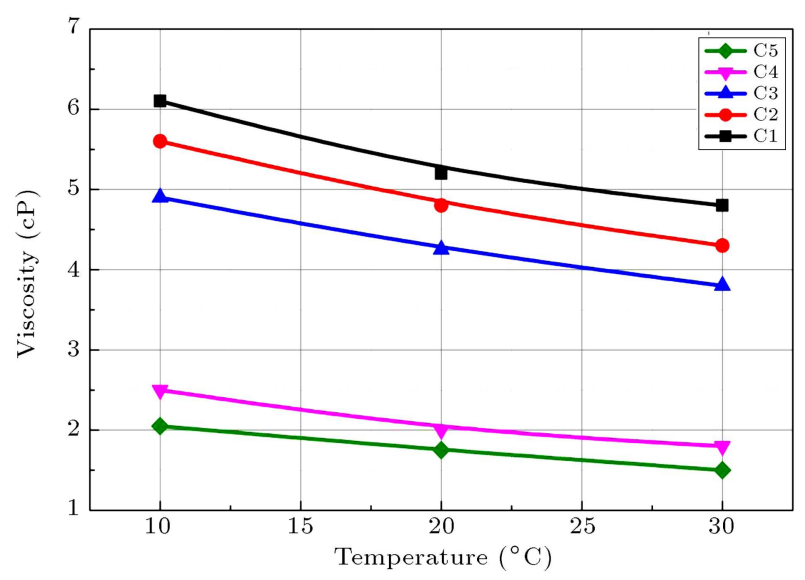

Figure 4. The relation between viscosity and temperature.

the change in gelling times of the mixtures used in the injection experiments with the ambient temperature.

Viscosity is defined as the resistance of a fluid to flow or the resistance to internal shear forces [14]. Brookfield DV III rheometer was applied to determine the viscosity of sodium silicate-glyoxal mixtures. Viscosity determination experiments were carried out at 3 different temperatures $\left(+10^{\circ} \mathrm{C},+20^{\circ} \mathrm{C}\right.$, and $\left.+30^{\circ} \mathrm{C}\right)$ and on 5 mixtures. The tests were carried out according to ASTM D 2196-15 [32]. The change in viscosity with temperature is given in Figure 4.

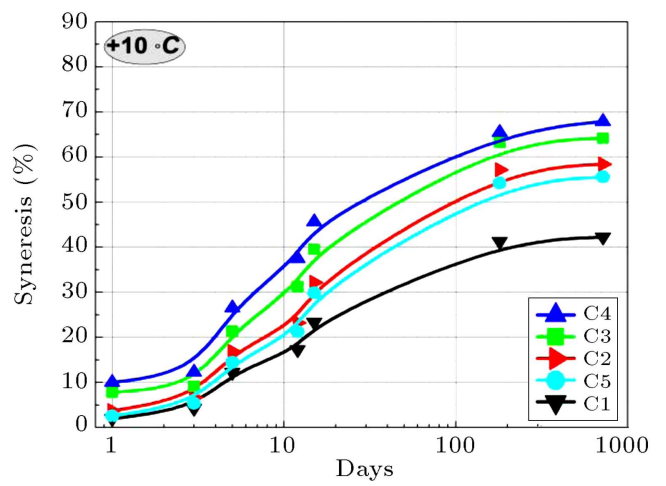

(a)
Syneresis is identified as the release of water caused by the shrinking gel over time following the gelling phase. The syneresis occurs in the most solid state following the fluid and plastic phases of gelling, and the water withdrawn is expressed as the ratio of the volume of the gel to the initial volume of the gel [31]. In the reaction after gelling, the silanol groups are converted into siloxane bonds and water is released (Eq. (3)):

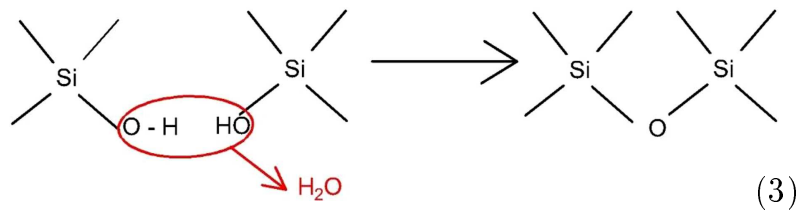

Time-dependent syneresis values were measured by storing the specimens, which completed the gelling time, at 3 different temperatures $\left(+10^{\circ} \mathrm{C},+20^{\circ} \mathrm{C}\right.$, and $\left.+30^{\circ} \mathrm{C}\right)$. The ambient temperature setting was done with Digital Fan Coil Room Thermostat, while syneresis measurements were carried out. The variation of syneresis with the curing time is shown in Figure 5. The effect of temperature on the syneresis of grouts is given in Figure 6. The relationship between silicate percentage and syneresis is given in Figure 7 .

\subsection{Groutability}

Groutability is defined as the ability to penetrate by

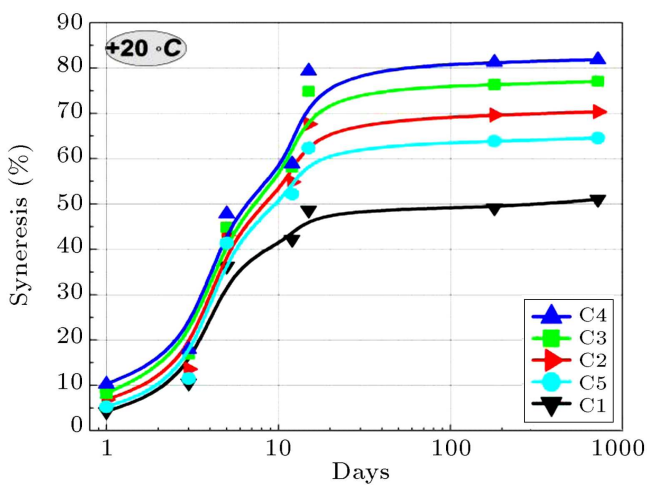

(b)

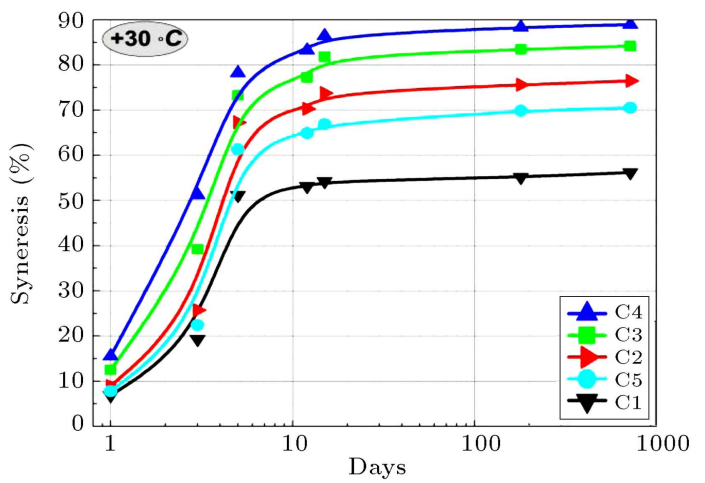

(c)

Figure 5. Variations of syneresis with time: (a) $+10^{\circ} \mathrm{C}$, (b) $+20^{\circ} \mathrm{C}$, and (c) $+30^{\circ} \mathrm{C}$. 


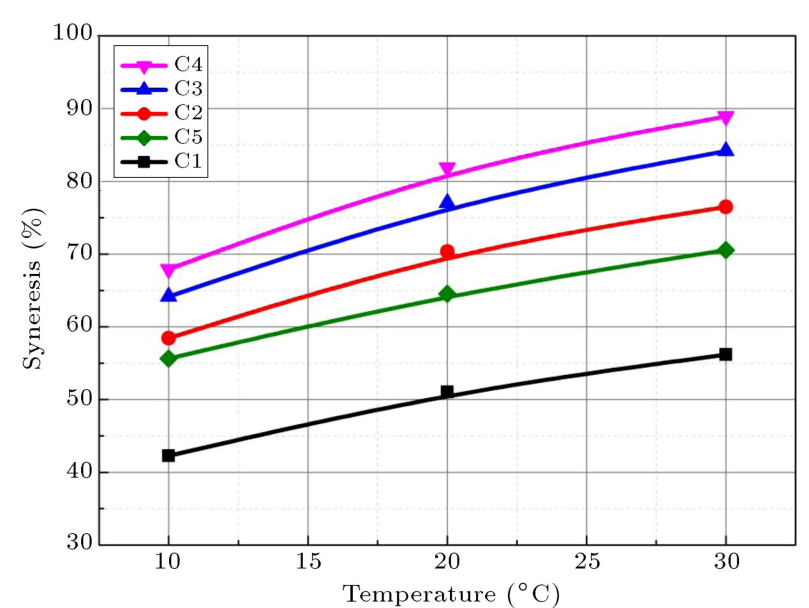

Figure 6. Relationship between syneresis and temperature.

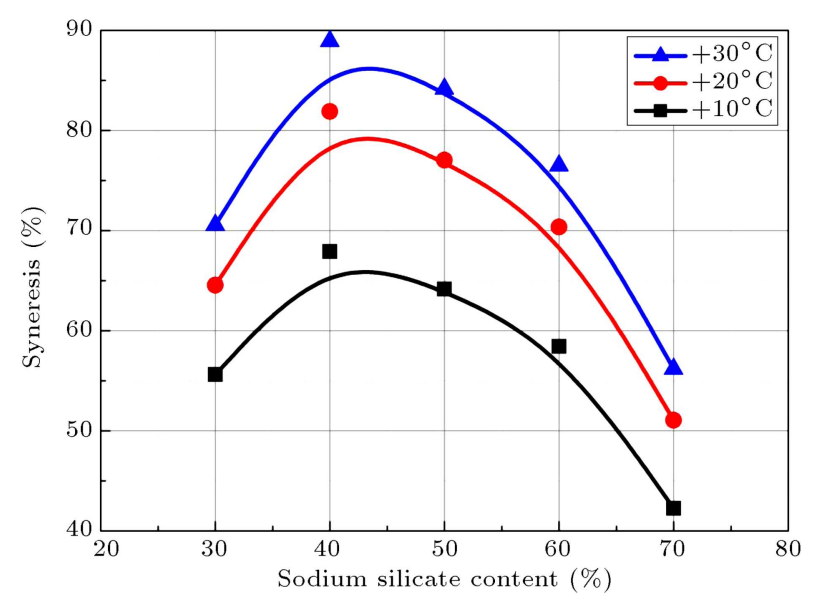

Figure 7. Syneresis variation with sodium silicate content (at the end of the 720th day).

grout to the porous material. It is a function of the rheological properties of grouts and the physical qualities of the soil $[1,33]$. After fully injecting the predetermined amount of grout into the specimens, the success of groutability was notable. The required amount of grout was determined based on the porosity of sand specimens at a relative density of $30 \%$. The groutability of sodium silicate-glyoxal grout into sand specimens with different gradations at a relative density of $30 \%$ was investigated, and the results are displayed in Figure 8.

\subsection{Unconfined Compressive Strength (UCS)}

The grouted sand specimens used for UCS tests were kept in a vertical position for nearly three days in molds, and they were then removed from molds, after which all of them were cured under water in tanks at three different temperatures of $10^{\circ} \mathrm{C}, 20^{\circ} \mathrm{C}$, and $30^{\circ} \mathrm{C}$ until testing time. The thermostat control heater and water circulating pump in the curing tank were used to adjust the desired temperatures throughout the curing

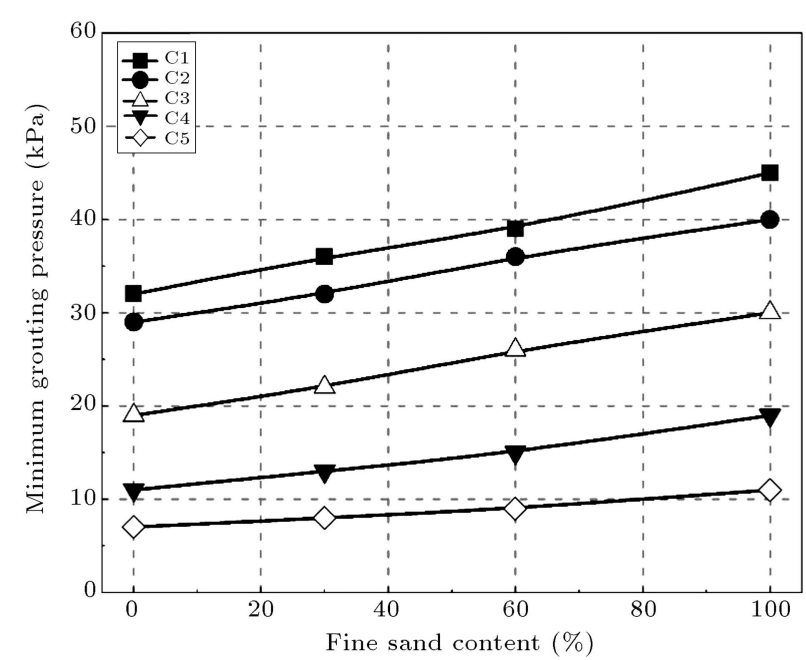

Figure 8. The changes in grouting pressure with fine sand content.

time. The desired temperature values were added to the digital display of the curing tank and, then, the temperature was adjusted. The samples were set to the curing temperature values at room temperature while performing UCS test.

Before conducting the UCS test, the granular filters at the top and bottom of injected specimens were cut off by the diamond blade saw and capped by means of plaster of Paris. The UCS tests in accordance with ASTM D4219-08 [34] were conducted on injected sand specimens cured on $3,7,14,28,56$, and 150 days. Figure 9 shows the UCS values of injected sand specimens over time. The changes in UCS of injected sand specimens on the 150th day with the curing temperature are given in Figure 10. The stress-strain relationships of the grouted samples at different temperatures on the 150th day are also given in Figures 11-13.

\subsection{Permeability}

Originally, the constant head permeability tests were performed on different graded ungrouted sand specimens at a relative density of $30 \%$ in line with ASTM D2434-68 [35], and their permeability values are given in Figure 14. Besides, the permeabilities of grouted sand specimens with different gradations and $30 \%$ relative density were studied by carrying out the permeability test (falling head) under the gradient of 20 in reference to ASTM D5856-15 [36]. Permeability measurements were made on days $7,28,56$, and 150. The specimens were kept in the curing tank where the UCS samples were stored until the testing time. While the experiments were carried out, the temperature of the room where the permeability tests were being carried out was adjusted to the temperature maintained for the curing time with Digital Fan Coil Room Thermostat. Figure 15 shows the permeability values of injected sand specimens over time. The 


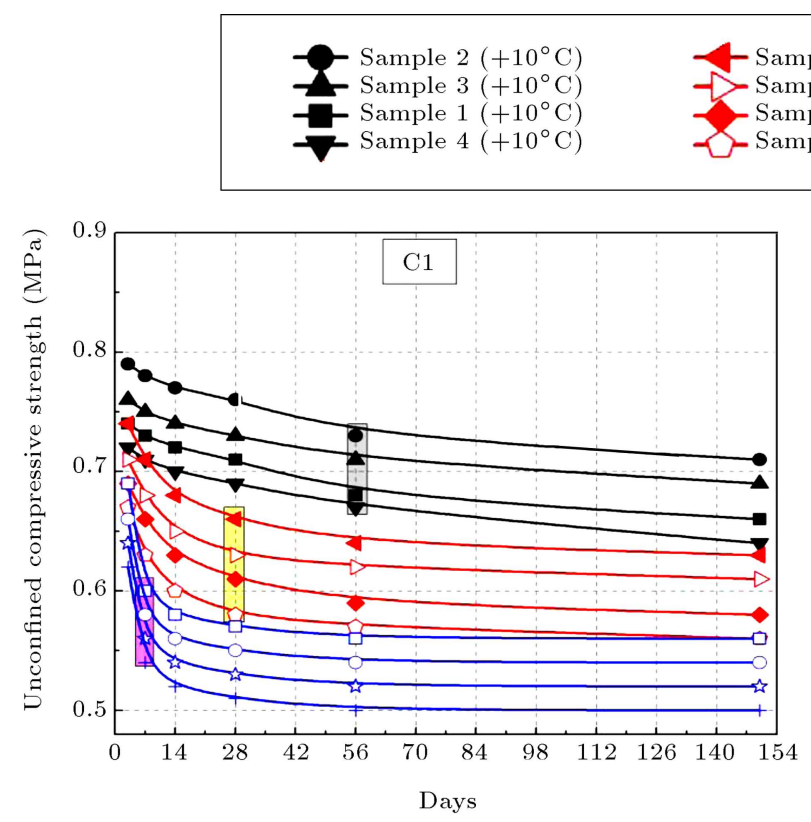

(a)

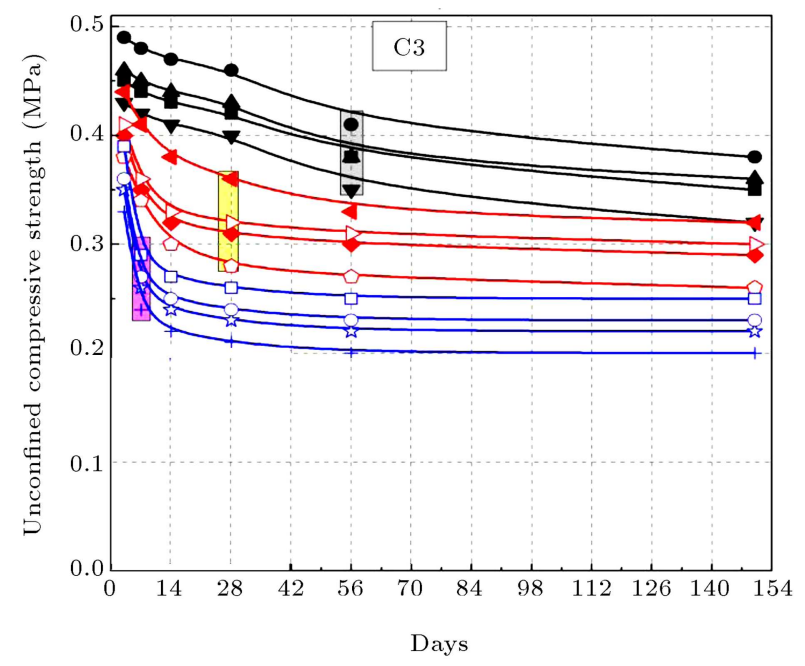

(c)

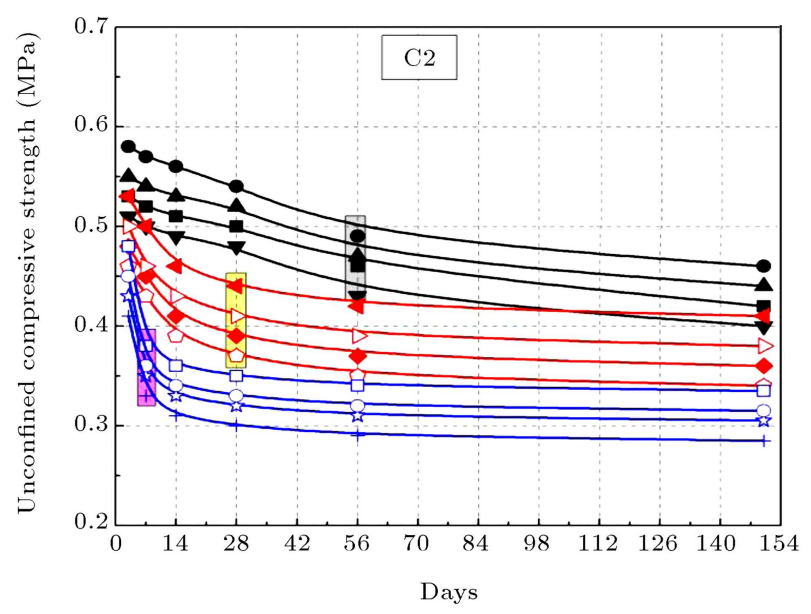

(b)

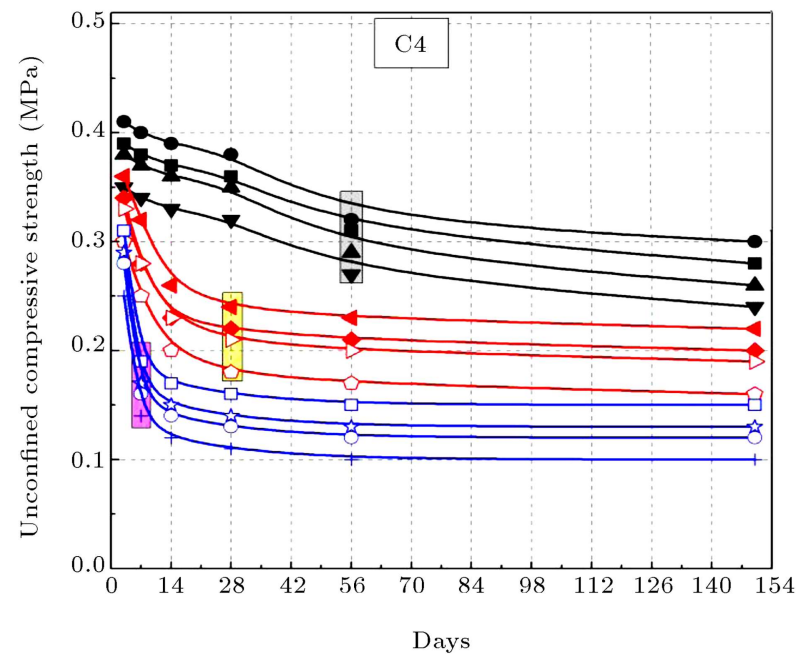

(d)

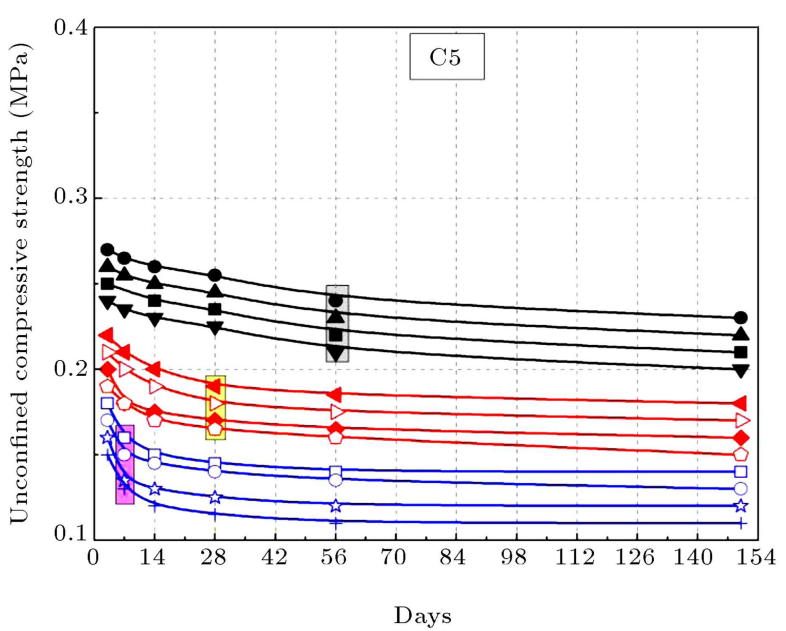

(e)

Figure 9. Unconfined Compressive Strength (UCS) variation of grouted sand samples with time. 


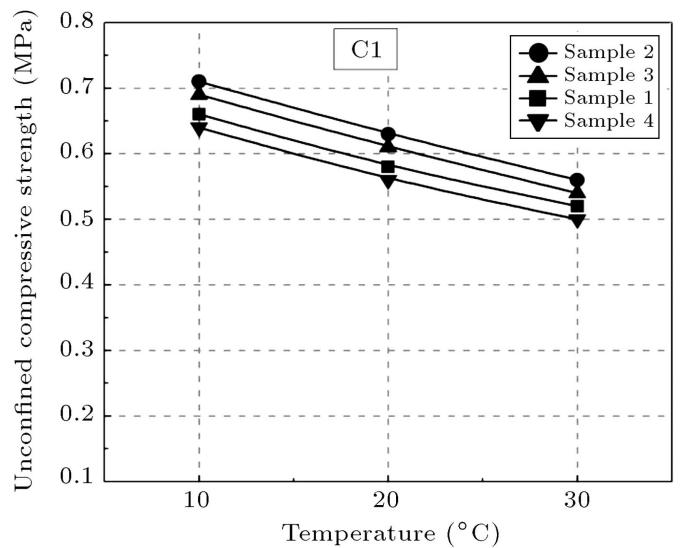

(a)

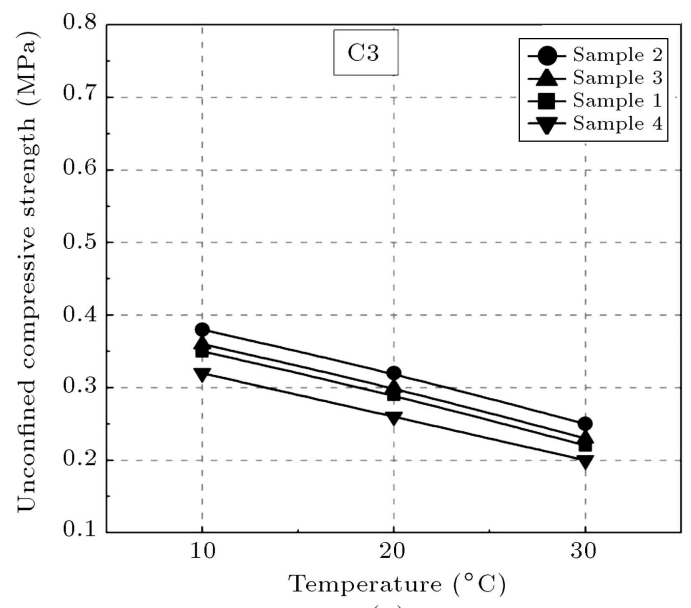

(c)

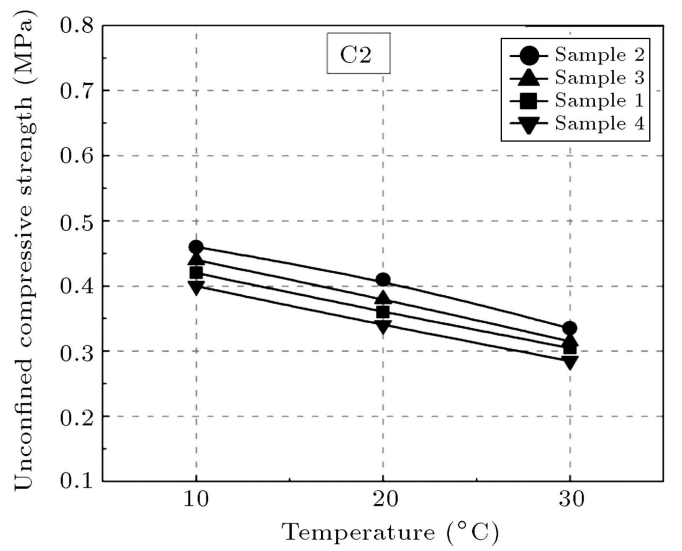

(b)

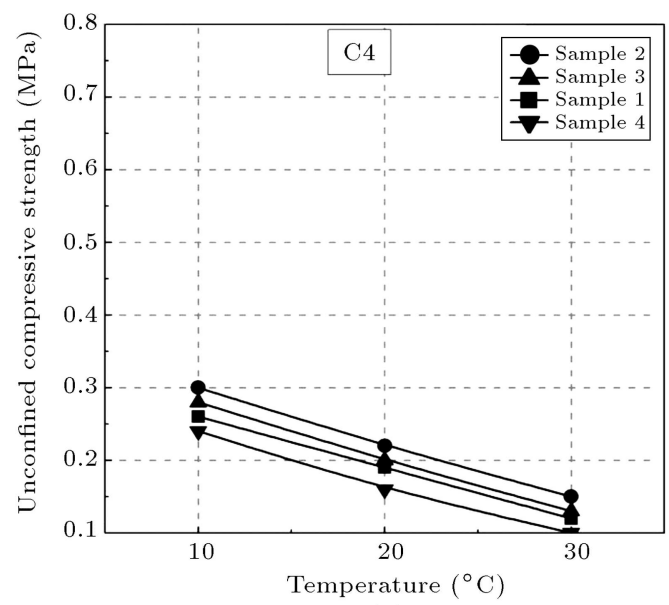

(d)

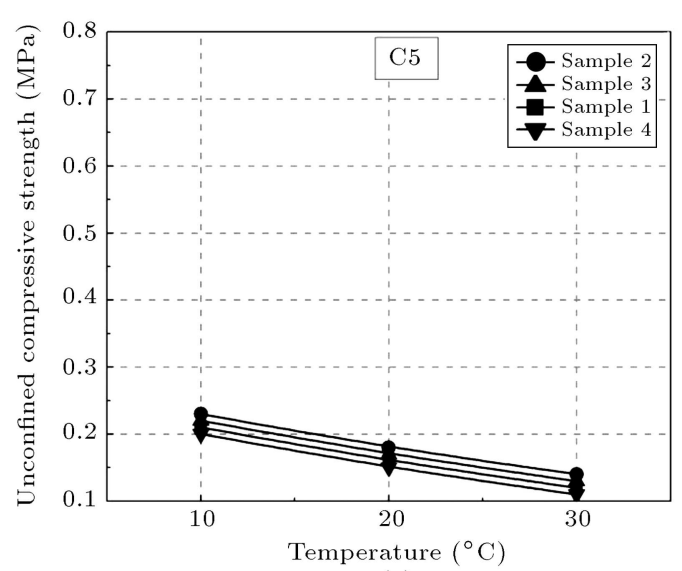

(e)

Figure 10. The changes in Unconfined Compressive Strength (UCS) of the grouted samples with temperature (150th day).

changes in the permeability of grouted sand specimens on the 150th day with curing temperatures are given in Figure 16.

\section{Results and discussion}

4.1. Gel time, viscosity, and syneresis

As seen in Figure 3, it was shown that the gelling times of sodium silicate-glyoxal mixtures changed between 66 and 213 minutes at $+10^{\circ} \mathrm{C}$, between 45 and 175 minutes at $+20^{\circ} \mathrm{C}$, and between 36 and 163 minutes at $+30^{\circ} \mathrm{C}$. As the ambient temperature increased, the reaction accelerated and the gelling times shortened accordingly. The average amount of shortening was $22 \%$ between $+10^{\circ} \mathrm{C}$ and $+20^{\circ} \mathrm{C}$, while it was $13 \%$ between $+20^{\circ} \mathrm{C}$ and $+30^{\circ} \mathrm{C}$ (Figure 3 ). 


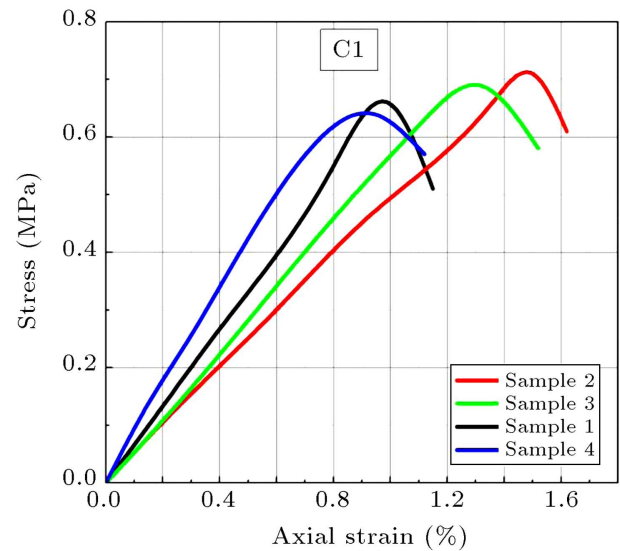

(a)

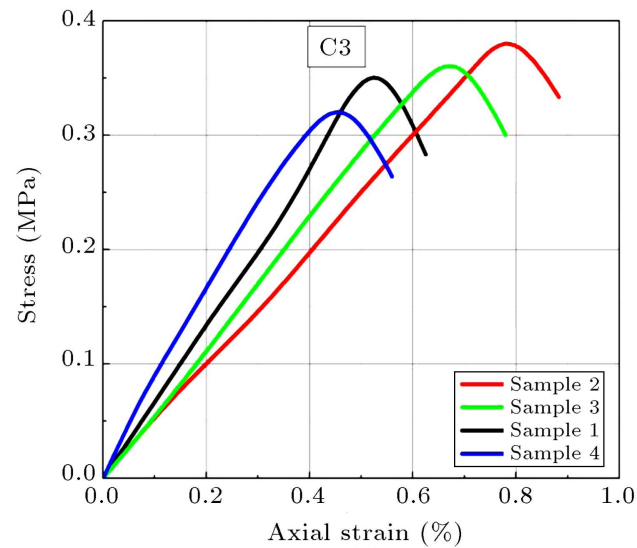

(c)

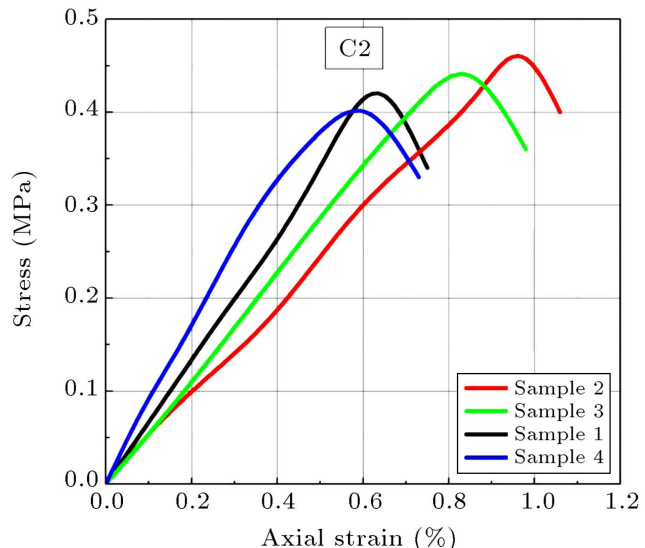

(b)

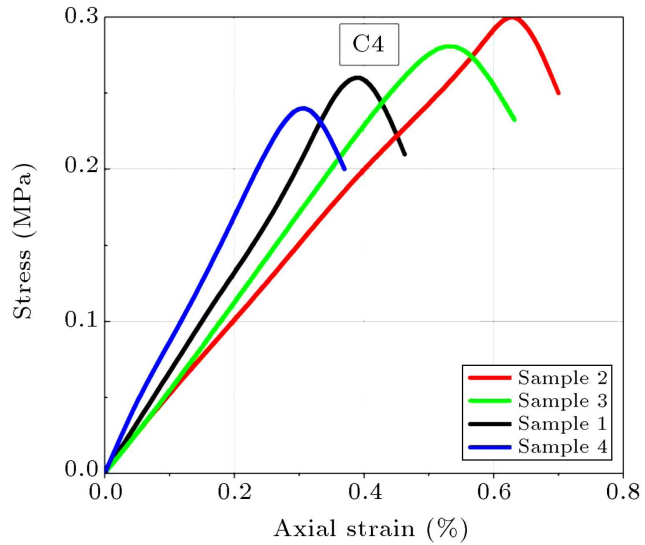

(d)

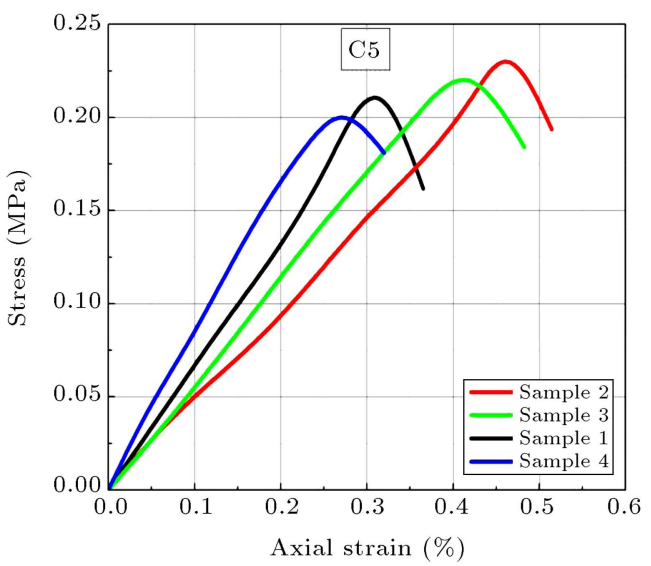

(e)

Figure 11. The stress-strain relationship of the grouted samples at $10^{\circ} \mathrm{C}(150$ th day).

The viscosity values of the sodium silicate-glyoxal mixtures ranged from $2.05 \mathrm{cP}$ to $6.10 \mathrm{cP}$ at $+10^{\circ} \mathrm{C}$, from $1.75 \mathrm{cP}$ to $5.20 \mathrm{cP}$ at $+20^{\circ} \mathrm{C}$, and from $1.50 \mathrm{cP}$ to $4.80 \mathrm{cP}$ at $+30^{\circ} \mathrm{C}$. Viscosity values decreased with the increasing temperature. This reduction was an average of $16 \%$ between $+10^{\circ} \mathrm{C}$ and $+20^{\circ} \mathrm{C}$, while it was an average of $11 \%$ between $+20^{\circ} \mathrm{C}$ and $+30^{\circ} \mathrm{C}$ (Figure 4).

The syneresis percentages of sodium silicateglyoxal mixtures ranged from $42 \%$ to $68 \%$ at $+10^{\circ} \mathrm{C}$, $51 \%$ to $82 \%$ at $+20^{\circ} \mathrm{C}$, and $56 \%$ to $71 \%$ at $+30^{\circ} \mathrm{C}$ at the end of the 720th day (Figures 5 and 6). Moreover, syneresis increased with the increasing temperature. This increase was $20 \%$ between $+10^{\circ} \mathrm{C}$ and $+20^{\circ} \mathrm{C}$ on average and, also, $9 \%$ between $+20^{\circ} \mathrm{C}$ and $+30^{\circ} \mathrm{C}$ (Figure 6). The amount of syneresis increased up to $40 \%$ silicate content and, then, began decreasing with a further increase in sodium silicate content (Figure 7). Syneresis increased with time. This increasing pattern slowed down on the 180th day in the specimens stored at $+10^{\circ} \mathrm{C}$, after the 18 th day in the specimens stored 

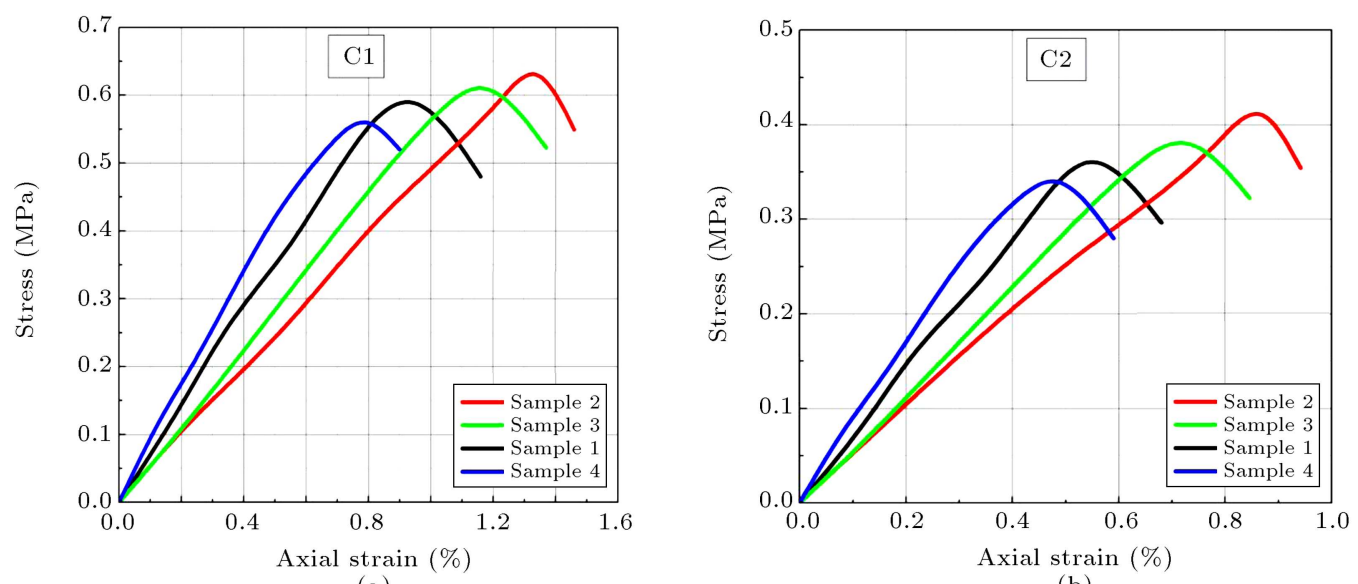

(a)

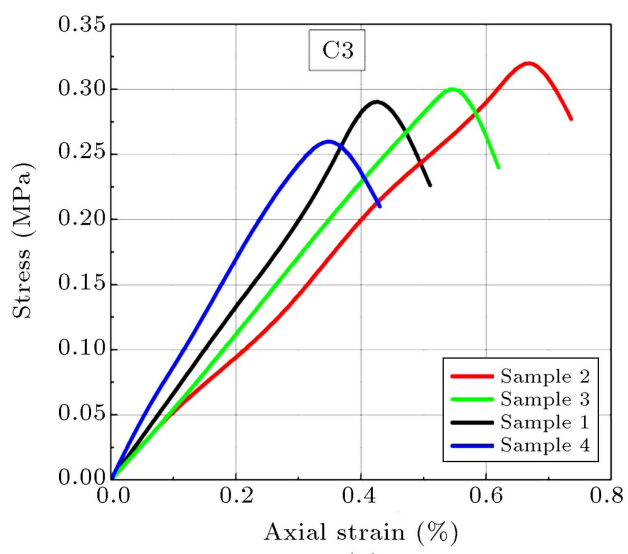

(c)

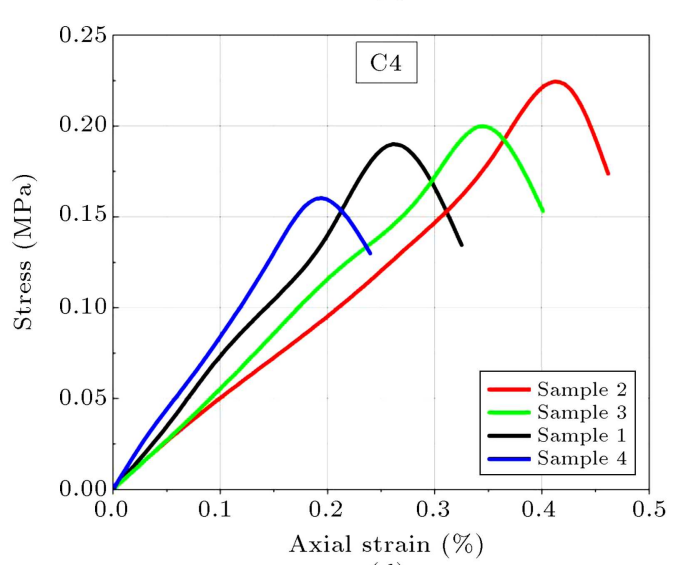

(d)

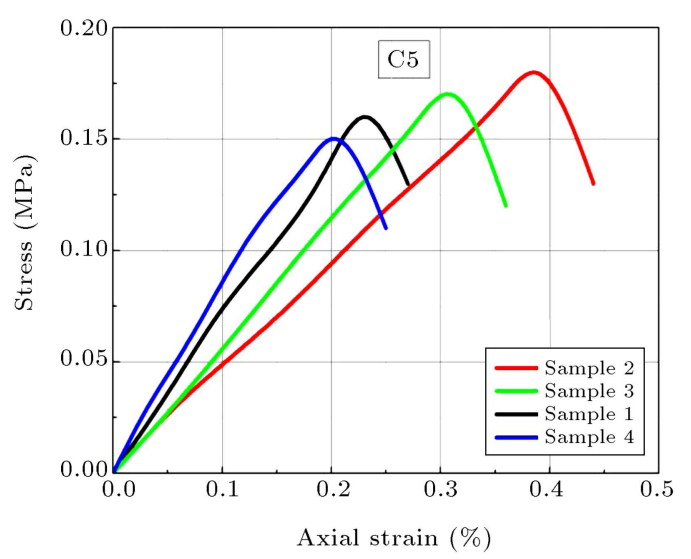

(e)

Figure 12. The stress-strain relationship of the grouted samples at $20^{\circ} \mathrm{C}(150$ th day).

at $+20^{\circ} \mathrm{C}$, and lastly after the 5 th day in the specimens stored at $+30^{\circ} \mathrm{C}$ (Figure 5). With an increase in temperature, the reaction accelerated and, thus, the syneresis developed more rapidly.

\subsection{Groutability}

The sand samples prepared at a relative density of $30 \%$ were simply grouted by sodium silicate-glyoxal grout at low grouting pressures (Figure 8). The minimum grouting pressures ranged from 7 to $45 \mathrm{kPa}$. The minimum grouting pressures increased with an increase in the percentage of sodium silicate and the percentage of fine grains.

\subsection{UCS}

UCS values of the specimens grouted with $\mathrm{C} 1$ mixture and stored at $+10^{\circ} \mathrm{C}$ were $0.66,0.71,0.69$, and 0.64 $\mathrm{MPa}$ for specimens 1, 2, 3, and 4 at the end of 150 days, respectively. The UCS values of the specimens stored at $+20^{\circ} \mathrm{C}$ were $0.58,0.63,0.61$, and $0.56 \mathrm{MPa}$ 


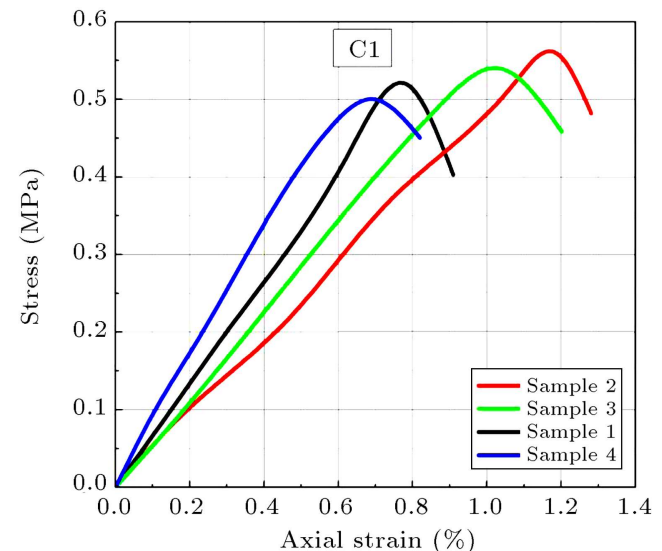

(a)

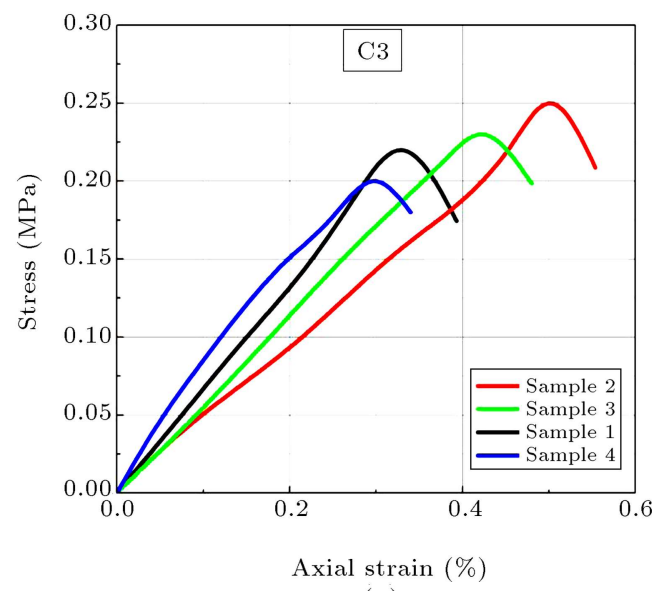

(c)

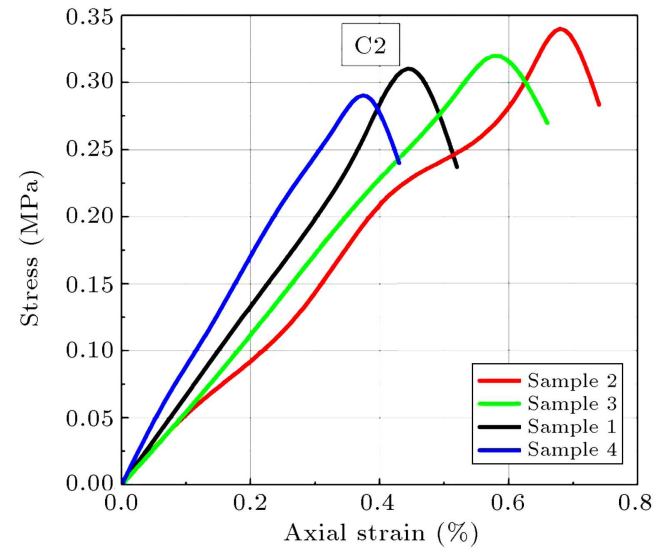

(b)

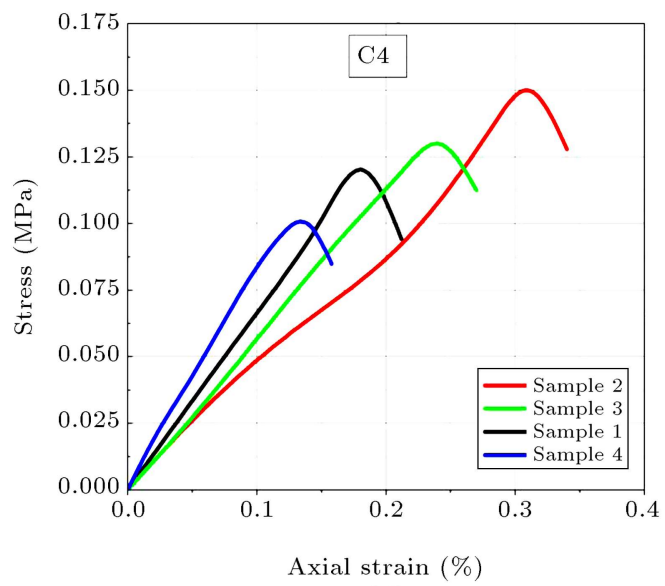

(d)

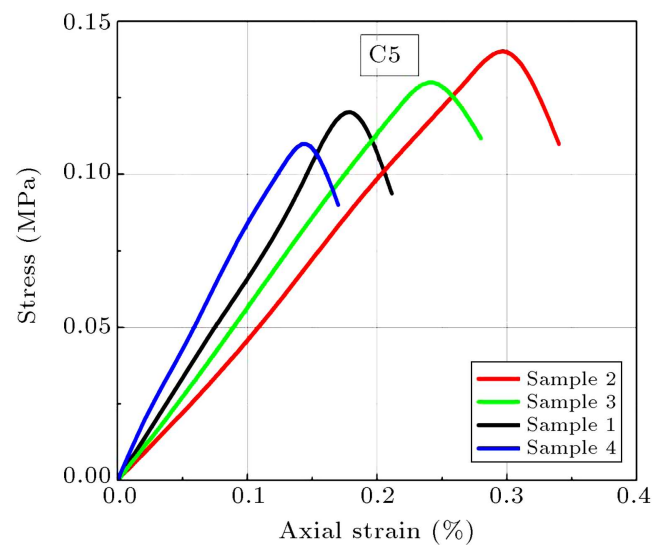

(e)

Figure 13. The stress-strain relationship of the grouted samples at $30^{\circ} \mathrm{C}(150$ th day).

for specimens $1,2,3$, and 4 at the end of 150 days, respectively. The UCS values of the specimens stored at $+30^{\circ} \mathrm{C}$ were $0.52,0.56,0.54$, and $0.50 \mathrm{MPa}$ for specimens $1,2,3$, and 4 at the end of 150 days, respectively (Figures 9 and 10 ).

UCS values of the specimens grouted with $\mathrm{C} 2$ mixture and stored at $+10^{\circ} \mathrm{C}$ were $0.42,0.46,0.44$, and $0.40 \mathrm{MPa}$ for specimens $1,2,3$, and 4 at the end of 150 days, respectively. The UCS values of the specimens stored at $+20^{\circ} \mathrm{C}$ were $0.36,0.41,0.38$, and
$0.34 \mathrm{MPa}$ for specimens $1,2,3$, and 4 at the end of 150 days, respectively. The UCS values of the specimens stored at $+30^{\circ} \mathrm{C}$ were $0.31,0.34,0.32$, and $0.29 \mathrm{MPa}$ for specimens 1, 2, 3, and 4 at the end of 150 days, respectively (Figures 9 and 10).

UCS values of the specimens grouted with C3 mixture and stored at $+10^{\circ} \mathrm{C}$ were $0.35,0.38,0.36$, and $0.32 \mathrm{MPa}$ for specimens $1,2,3$, and 4 at the end of 150 days, respectively. The UCS values of the specimens stored at $+20^{\circ} \mathrm{C}$ were $0.29,0.32,0.30$, and 


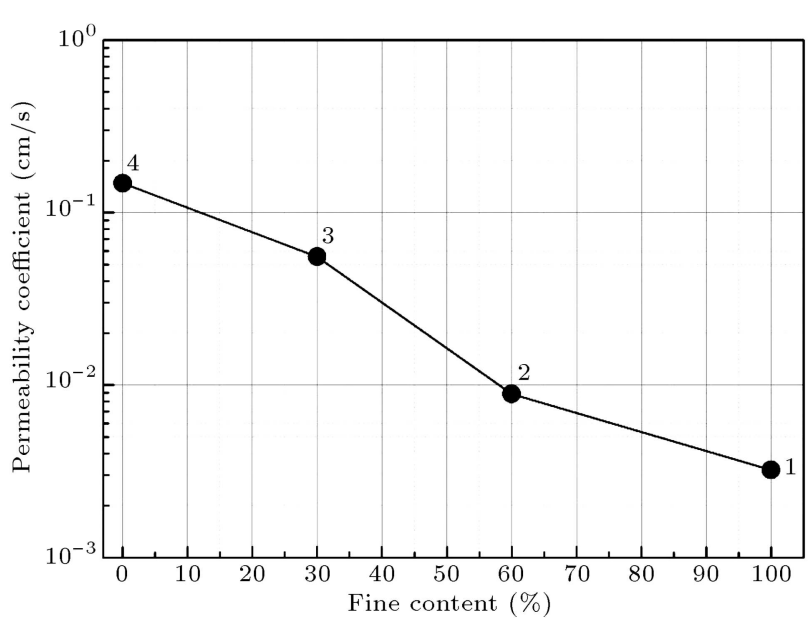

Figure 14. Permeability values of ungrouted sand samples.

$0.26 \mathrm{MPa}$ for specimens $1,2,3$, and 4 at the end of 150 days, respectively. The UCS values of the specimens stored at $+30^{\circ} \mathrm{C}$ were $0.22,0.25,0.23$, and $0.20 \mathrm{MPa}$ for specimens $1,2,3$, and 4 at the end of 150 days, respectively (Figures 9 and 10).

UCS values of the specimens grouted with $\mathrm{C} 4$ mixture and stored at $+10^{\circ} \mathrm{C}$ were $0.28,0.30,0.26$, and $0.24 \mathrm{MPa}$ for specimens $1,2,3$, and 4 at the end of 150 days, respectively. The UCS values of the specimens stored at $+20^{\circ} \mathrm{C}$ were $0.20,0.22,0.19$, and $0.16 \mathrm{MPa}$ for specimens $1,2,3$, and 4 at the end of 150 days, respectively. The UCS values of the specimens stored at $+30^{\circ} \mathrm{C}$ were $0.13,0.15,0.12$, and $0.10 \mathrm{MPa}$ for specimens $1,2,3$, and 4 at the end of 150 days, respectively (Figures 9 and 10).

UCS values of the specimens grouted with C5 mixture and stored at $+10^{\circ} \mathrm{C}$ were $0.21,0.23,0.22$, and $0.20 \mathrm{MPa}$ for specimens $1,2,3$, and 4 at the end of 150 days, respectively. The UCS values of the specimens stored at $+20^{\circ} \mathrm{C}$ were $0.16,0.18,0.17$, and $0.15 \mathrm{MPa}$ for specimens $1,2,3$, and 4 at the end of 150 days, respectively. The UCS values of the specimens stored at $+30^{\circ} \mathrm{C}$ were $0.12,0.14,0.13$, and $0.11 \mathrm{MPa}$ for specimens $1,2,3$, and 4 at the end of 150 days, respectively (Figures 9 and 10).

The UCS values of the grouted samples decreased with time. This decreasing trend slowed down after the 56 th day in the samples stored at $+10^{\circ} \mathrm{C}$, slowed down after the 28th day in the samples stored at $+20^{\circ} \mathrm{C}$, and then again slowed down after the 7 th day in the ones stored at $+30^{\circ} \mathrm{C}$. It was seen that the UCS values of the samples stored at $+10^{\circ} \mathrm{C}$ grouted with $\mathrm{C} 1, \mathrm{C} 2$, C3, C4, and C5 mixtures at the end of the 150th day experienced $10 \% 21 \%, 23 \%, 30 \%$, and $16 \%$ decreases, respectively. On the other hand, it was observed that, at the end of the 150th day, the UCS values of the samples grouted with mixtures of $\mathrm{C} 1, \mathrm{C} 2, \mathrm{C} 3, \mathrm{C} 4$, and $\mathrm{C} 5$ and stored at $+20^{\circ} \mathrm{C}$ experienced $15 \%, 24 \%$,
$28 \%, 42 \%$, and $20 \%$ decreases, respectively. In the same way, the samples grouted with mixtures of $\mathrm{C} 1$, $\mathrm{C} 2, \mathrm{C} 3, \mathrm{C} 4$, and $\mathrm{C} 5$ and stored at $+30^{\circ} \mathrm{C}$ were seen to have experienced a decrease of $19 \%, 30 \%, 37 \%, 56 \%$, and $24 \%$ in UCS values at the end of the 150 th day. This time-dependent decrease in UCS was caused by syneresis. When the syneresis phenomenon occurs, the sample shrinks, the capillary fissures form, and the strength decreases accordingly. The greatest decrease of the UCS values was seen in G4 grouted mixtures with the highest percentage of syneresis, while the lowest decrease in the UCS values was observed in G1 grouted mixtures with the lowest percentage of syneresis (Figure 9).

The strength decreased with the increasing temperature (Figure 10). For example, the UCS values of the samples stored at $+10^{\circ} \mathrm{C}$ are 1.24 times more than those of the samples held at $+20^{\circ} \mathrm{C}$, while they are 1.63 times higher than the unconfined compression of the samples stored at $+30^{\circ} \mathrm{C}$. This decrease in strength is related to both the formed gel structure and syneresis. An increase in temperature accelerates the reactions. As the reaction accelerates, a weaker gel forms and more syneresis occurs, decreasing the strength. In addition, while the ultimate strength is reached later at low temperatures, it is reached earlier at higher temperatures. For example, while the samples held at $+10^{\circ} \mathrm{C}$ reach the ultimate strengths on average on the 150 th day, the samples stored at $+20^{\circ} \mathrm{C}$ reach the ultimate strengths on average on the 56th day. In addition, the samples stored at $+30^{\circ} \mathrm{C}$ can be seen to reach the ultimate strengths on the 28th day (Figure 9 ).

As the content of sodium silicate increased, the strength increased, too. The highest strength is seen in the samples grouted with $\mathrm{C} 1$ blends, while the lowest strength is seen in blends grouted with C5 blends (Figures 9 and 10).

The gradation of sand grains has an effect on the strength. The highest strength is observed in the grouted sand samples 2, while the lowest strength is seen in the ones grouted with sand samples 4 (Figures 9 and 10).

Figures 11-13 show that the relationship between the stress and the strain before failure becomes almost linear and the strains range from $0.13 \%$ to $1.5 \%$ at failure. This is a typical brittle behavior of sodium silicatereactant grouted sands $[17,19,20,24,37]$. As the temperature increases, the strains at failure increase, too.

Based on the laboratory test results, a linear regression analysis was performed in order to correlate the UCS with temperature $(t)$, sodium Silicate Content (SC), sand gradation $\left(d_{15}\right)$, and syneresis $\left(S_{y}\right)$, which were taken as descriptor variables. The empirical equation and the corresponding determination coefficient $\left(R^{2}\right)$ obtained from the regression analysis are as follows (Eq. (4)): 

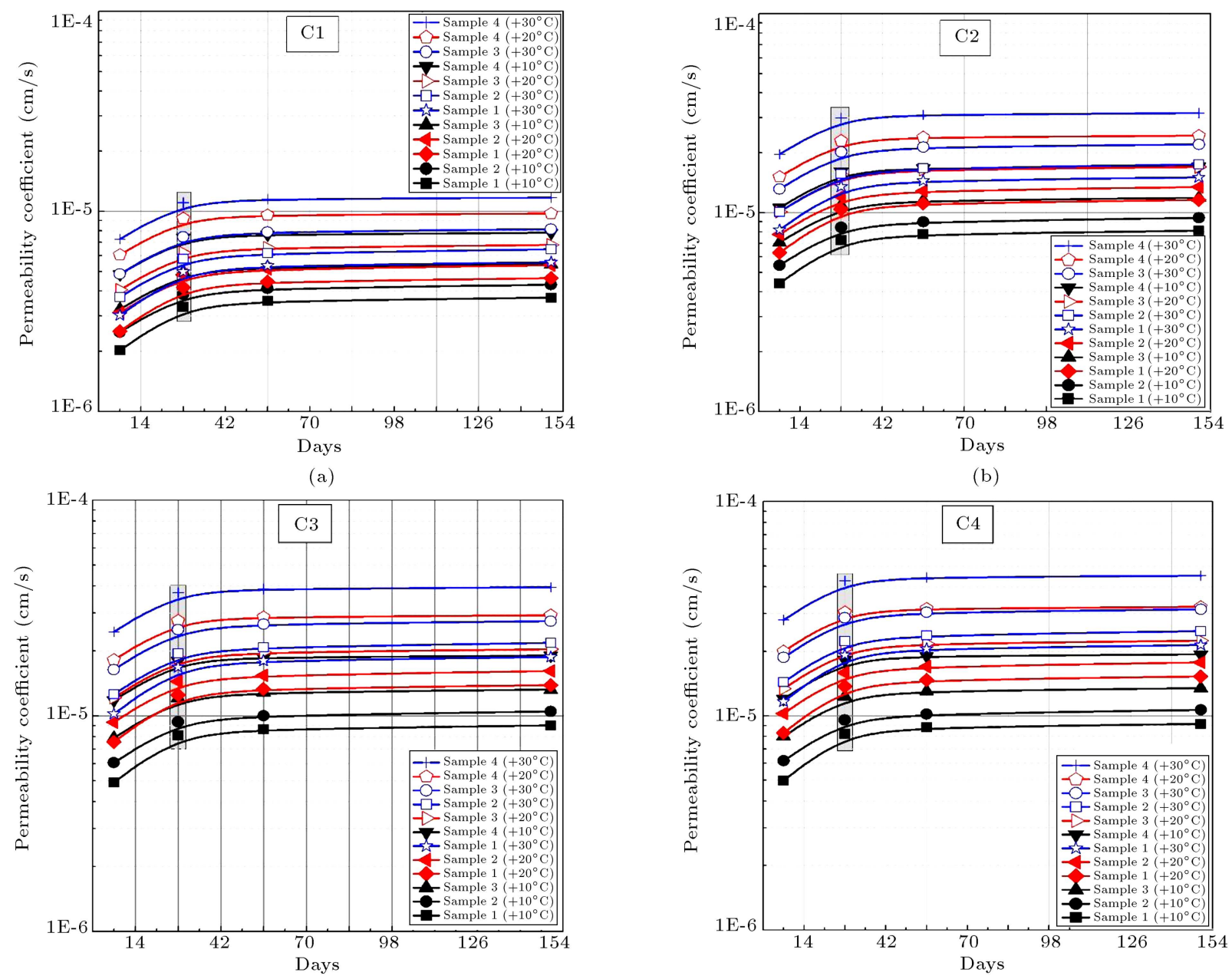

(c)

(d)

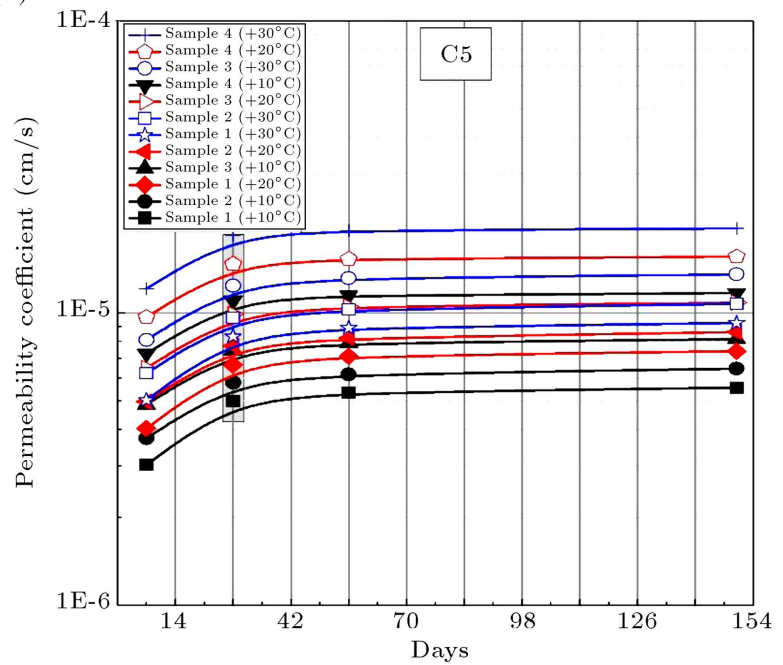

(e)

Figure 15. Permeability variation of grouted sand samples with time.

$$
\begin{aligned}
U C S & =7.295 \times 10^{-2}-7.1 \times 10^{-5} \times t-3.81 \\
& \times 10^{-3} \times T+10^{-2} \times S C-8.895 \times 10^{-2} \times d_{15} \\
& -2.25 \times 10^{-3} \times S_{y}
\end{aligned}
$$

$$
R^{2}=0.95
$$

\subsection{Permeability}

The permeability values of the samples grouted with $\mathrm{C} 1$ mixture and stored at $+10^{\circ} \mathrm{C}$ ranged from $3.70 \times$ 


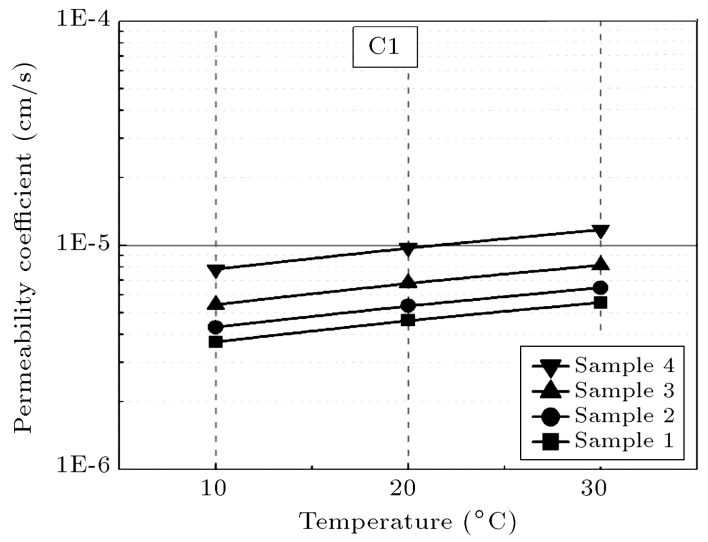

(a)

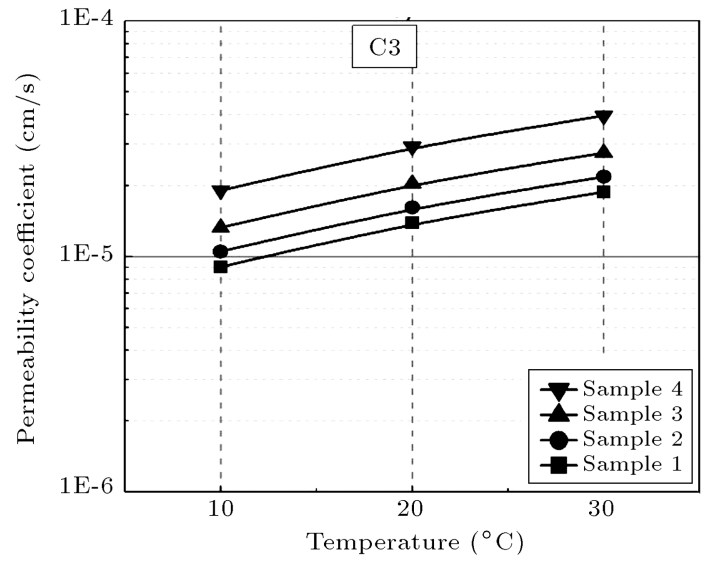

(c)

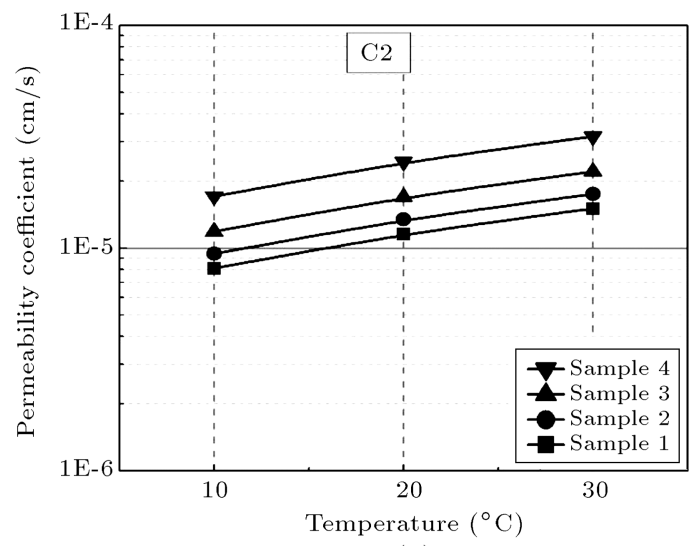

(b)

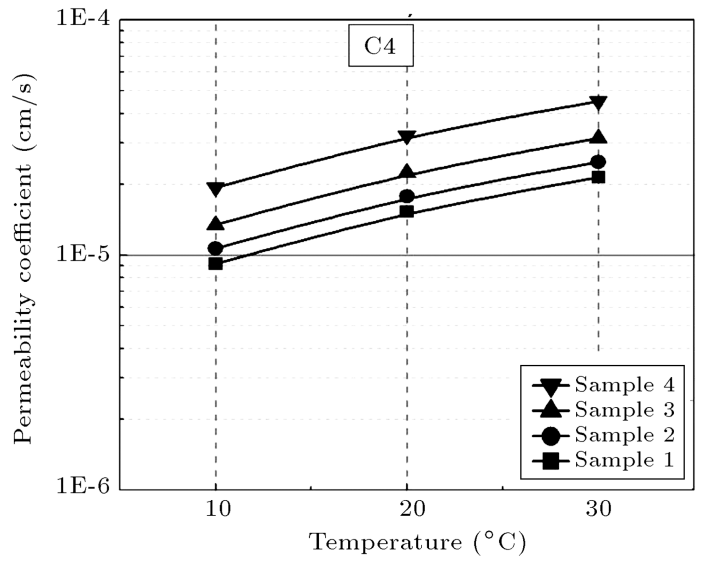

(d)

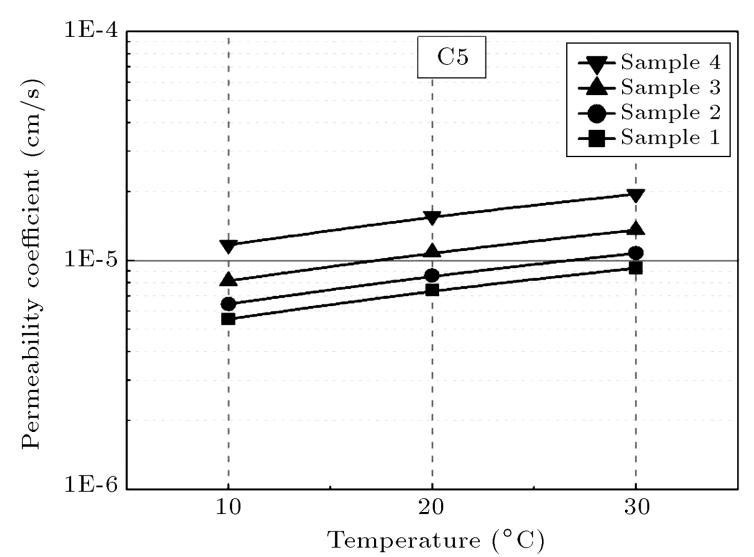

(e)

Figure 16. Permeability variation of grouted sand samples with temperature (150th day).

$10^{-6} \mathrm{~cm} / \mathrm{s}$ to $7.81 \times 10^{-6}$ at the end of the 150 th day. The permeability values of the samples stored at $+20^{\circ} \mathrm{C}$ ranged from $4.63 \times 10^{-6} \mathrm{~cm} / \mathrm{s}$ to $9.76 \times 10^{-6} \mathrm{~cm} / \mathrm{s}$ at the end of the 150th day. The permeability values of the samples stored at $+30^{\circ} \mathrm{C}$ ranged from $5.56 \times 10^{-6} \mathrm{~cm} / \mathrm{s}$ to $1.17 \times 10^{-5} \mathrm{~cm} / \mathrm{s}$ at the end of the 150 th day (Figures 15 and 16$)$.

The permeability values of the samples grouted with $\mathrm{C} 2$ mixture and stored at $+10^{\circ} \mathrm{C}$ ranged from $8.10 \times 10^{-6} \mathrm{~cm} / \mathrm{s}$ to $1.71 \times 10^{-5} \mathrm{~cm} / \mathrm{s}$ at the end of the 150 th day. The permeability values of the samples stored at $+20^{\circ} \mathrm{C}$ ranged from $1.16 \times 10^{-5} \mathrm{~cm} / \mathrm{s}$ to $2.44 \times 10^{-5} \mathrm{~cm} / \mathrm{s}$ at the end of the 150 th day. The permeability values of the samples stored at $+30^{\circ} \mathrm{C}$ ranged from $1.50 \times 10^{-5} \mathrm{~cm} / \mathrm{s}$ to $3.17 \times 10^{-5} \mathrm{~cm} / \mathrm{s}$ at the end of the 150th day (Figures 15 and 16).

The permeability values of the samples grouted with $\mathrm{C} 3$ mixture and stored at $+10^{\circ} \mathrm{C}$ ranged from $9.03 \times 10^{-6} \mathrm{~cm} / \mathrm{s}$ to $1.90 \times 10^{-5} \mathrm{~cm} / \mathrm{s}$ at the end of the 150 th day. The permeability values of the samples 
stored at $+20^{\circ} \mathrm{C}$ ranged from $1.39 \times 10^{-5} \mathrm{~cm} / \mathrm{s}$ to $2.93 \times 10^{-5} \mathrm{~cm} / \mathrm{s}$ at the end of the 150 th day. The permeability values of the samples stored at $+30^{\circ} \mathrm{C}$ ranged from $1.88 \times 10^{-5} \mathrm{~cm} / \mathrm{s}$ to $3.95 \times 10^{-5} \mathrm{~cm} / \mathrm{s}$ at the end of the 150th day (Figures 15 and 16).

The permeability values of the samples grouted with $\mathrm{C} 4$ mixture and stored at $+10^{\circ} \mathrm{C}$ ranged from $9.17 \times 10^{-6} \mathrm{~cm} / \mathrm{s}$ to $1.93 \times 10^{-5} \mathrm{~cm} / \mathrm{s}$ at the end of the 150 th day. The permeability values of the samples stored at $+20^{\circ} \mathrm{C}$ ranged from $1.53 \times 10^{-5} \mathrm{~cm} / \mathrm{s}$ to $3.22 \times 10^{-5} \mathrm{~cm} / \mathrm{s}$ at the end of the $150 \mathrm{th}$ day, while the permeability values of the samples stored at $+30^{\circ} \mathrm{C}$ ranged from $2.14 \times 10^{-5} \mathrm{~cm} / \mathrm{s}$ to $4.51 \times 10^{-5} \mathrm{~cm} / \mathrm{s}$ at the end of the 150th day (Figures 15 and 16).

The permeability values of the samples grouted with $\mathrm{C} 5$ mixture and stored at $+10^{\circ} \mathrm{C}$ ranged from $5.56 \times 10^{-6} \mathrm{~cm} / \mathrm{s}$ to $1.17 \times 10^{-5} \mathrm{~cm} / \mathrm{s}$ at the end of the 150 th day. The permeability values of the samples stored at $+20^{\circ} \mathrm{C}$ ranged from $7.41 \times 10^{-6} \mathrm{~cm} / \mathrm{s}$ to $1.56 \times 10^{-5} \mathrm{~cm} / \mathrm{s}$ at the end of the $150 \mathrm{th}$ day. The permeability values of the samples stored at $+30^{\circ} \mathrm{C}$ ranged from $9.26 \times 10^{-6} \mathrm{~cm} / \mathrm{s}$ to $1.95 \times 10^{-5} \mathrm{~cm} / \mathrm{s}$ at the end of the 150th day (Figures 15 and 16).

The permeability values of the ungrouted samples ranged from $3.22 \times 10^{-3}$ to $1.48 \times 10^{-1} \mathrm{~cm} / \mathrm{s}$. When sodium silicate-glyoxal was injected into the samples, the permeability values decreased between two to five orders of magnitude (Figures 14 and 16).

The permeability values of the grouted samples decreased with time. This decrease was seen to slow down after the 28th day. In the grouted samples, the permeability values decreased by $70 \%$ between the 7 th and 150th days, respectively (Figure 15).

The permeability values increased with the increasing temperature. This increase was seen to be 1.5 times between the samples stored at $+10^{\circ} \mathrm{C}$ and those stored at $+20^{\circ} \mathrm{C}$, while it was 1.3 times between the samples stored at $+20^{\circ} \mathrm{C}$ and those at $+30^{\circ} \mathrm{C}$. The reaction in the gel was accelerated with the temperature increase. The acceleration of the reaction caused a weaker gel formation and increased syneresis. This increased permeability by increasing the voids in the gel (Figure 16).

The lowest permeability values were seen in the samples grouted with $\mathrm{C} 1$ mixtures, whereas the highest permeability values were seen in the mixtures grouted with C4 (Figures 15 and 16).

The permeability was also affected by gradation. The highest permeability values were observed in the sand sample 4 (medium sand), while the lowest permeability values were observed in the sand sample 1 (fine sand). Increasing the ratio of fine sand decreased the permeability values (Figures 15 and 16).

\subsection{Discussion}

Given in Table 4 are the UCS values of sodium silicate-based grouted sands provided by several researchers $[20,24,37,38]$. As seen from the table, the UCS values differ from each other due to the type of reactant, silicate content, curing time, and temperature. In addition, it was shown in this study that the

Table 4. The Unconfined Compressive Strength (UCS) values of silicate grouted sand provided by some researchers.

\begin{tabular}{|c|c|c|c|c|c|c|}
\hline $\begin{array}{c}\text { Soil } \\
\text { properties }\end{array}$ & $\begin{array}{l}\text { Chemical } \\
\text { combination }\end{array}$ & $\begin{array}{l}\text { Dr } \\
(\%)\end{array}$ & $\begin{array}{l}\text { Curing } \\
\text { time }\end{array}$ & $\begin{array}{c}\text { Curing } \\
\text { temperature } \\
\left({ }^{\circ} \mathrm{C}\right) \\
\end{array}$ & $\begin{array}{c}\text { Unconfined } \\
\text { compressive } \\
\text { strength (MPa) }\end{array}$ & Researchers \\
\hline $\begin{array}{l}\text { Medium to } \\
\text { coarse sand }\end{array}$ & $\begin{array}{l}\text { Sodium silicate }+ \\
\text { dimethyl ester }+ \text { water }\end{array}$ & - & 28 days & 23 & $0.7-0.10$ & $\begin{array}{c}\text { Gonzalez and } \\
\text { Vipulanandan [37] }\end{array}$ \\
\hline Fine sand & $\begin{array}{c}\text { Sodium silicate }+ \text { polymer }+ \\
\text { mineral acid }+ \text { calcium carbonate }\end{array}$ & - & 28 days & - & $1.0-5.50$ & Thatur et al. [38] \\
\hline Medium sand & $\begin{array}{l}\text { Sodium silicate }+ \\
\text { inorganic reactant }+ \text { water }\end{array}$ & 45 & 24 hours & - & 0.065 & Porcino et al. [20] \\
\hline $\begin{array}{l}\text { Medium and } \\
\text { coarse sand }\end{array}$ & $\begin{array}{l}\text { Sodium silicate }+ \\
\text { inorganic reactant }+ \text { water }\end{array}$ & 70 & 80 days & 23 & $0.026-0.124$ & Porcino et al. [24] \\
\hline \multirow[t]{3}{*}{$\begin{array}{l}\text { Fine to } \\
\text { medium sand }\end{array}$} & Sodium silicate + glyoxal + water & 30 & 150 days & 10 & $0.20-0.71$ & In this research \\
\hline & & & & 20 & $0.15-0.61$ & \\
\hline & & & & 30 & $0.11-0.56$ & \\
\hline
\end{tabular}


Table 5. The permeability values of the silicate grouted sand provided by some researchers.

\begin{tabular}{|c|c|c|c|c|c|c|}
\hline $\begin{array}{c}\text { Soil } \\
\text { properties }\end{array}$ & $\begin{array}{c}\text { Chemical } \\
\text { combination }\end{array}$ & $\begin{array}{l}\text { Dr } \\
(\%)\end{array}$ & $\begin{array}{l}\text { Curing } \\
\text { time }\end{array}$ & $\begin{array}{c}\text { Curing } \\
\text { temperature } \\
\left({ }^{\circ} \mathrm{C}\right) \\
\end{array}$ & $\begin{array}{c}\text { Permeability } \\
\text { coefficient } \\
(\mathrm{cm} / \mathrm{s}) \\
\end{array}$ & Researchers \\
\hline Medium sand & $\begin{array}{l}\text { Sodium silicate }+ \\
\text { formamide }+ \text { calcium } \\
\text { chloride }+ \text { water }\end{array}$ & - & 7 days & - & $1.9 \times 10^{-5}-5.0 \times 10^{-5}$ & $\begin{array}{l}\text { Bodocsi and } \\
\text { Bowers [39] }\end{array}$ \\
\hline $\begin{array}{l}\text { Poorly graded } \\
\text { sand with } \\
\text { some gravel }\end{array}$ & $\begin{array}{l}\text { Sodium silicate }+ \\
\text { ethyl acetate }+ \\
\text { formamide }+ \text { water }\end{array}$ & - & $\begin{array}{l}17 \text { to } \\
24 \text { months }\end{array}$ & - & $6.0 \times 10^{-5}-5.0 \times 10^{-4}$ & Krizek and Spino [40] \\
\hline $\begin{array}{l}\text { Fine to } \\
\text { medium sand }\end{array}$ & $\begin{array}{l}\text { Sodium silicate }+ \\
\text { formamide+ water }\end{array}$ & $30-50-70$ & 150 days & 20 & $22.50 \times 10^{-5}-1.26 \times 10^{-4}$ & $\begin{array}{l}\text { Mollamahmutoglu } \\
\text { and Avci [41] }\end{array}$ \\
\hline \multirow[t]{3}{*}{$\begin{array}{l}\text { Fine to } \\
\text { medium sand }\end{array}$} & $\begin{array}{l}\text { Sodium silicate }+ \\
\text { glyoxal+ water }\end{array}$ & 30 & 150 days & 10 & $3.70 \times 10^{-6}-1.93 \times 10^{-5}$ & In this research \\
\hline & & & & 20 & $4.63 \times 10^{-6}-3.22 \times 10^{-5}$ & \\
\hline & & & & 30 & $5.56 \times 10^{-6}-4.51 \times 10^{-5}$ & \\
\hline
\end{tabular}

effect of temperature variation had considerable effect on the UCS of the silicate grouted sand.

The permeability test results provided by earlier researchers on the sodium silicate-based grouted sands are given in Table 5 comparatively. As seen from the table, there is no information about the curing temperature presented by other researchers [39-40]. However, Mollamahmutoglu and Avci [41] provided permeability test results at a temperature of $20^{\circ} \mathrm{C}$, and showed that the curing temperature had an effect on the silicate grouted sand.

\section{Conclusions}

The following are the main conclusions obtained from this experimental study:

- The gelling times shortened with an increase in the ambient temperature;

- The viscosity values decreased with the increasing temperature;

- Syneresis increased with the increased temperature;

- The unconfined compression strengths of the grouted samples decreased with time. This decrease was seen to be slowing down after the 56 th day in the samples stored at $+10^{\circ} \mathrm{C}$ and, then, slowed down after the 28 th day in the samples stored at $+20^{\circ} \mathrm{C}$; in addition, this slowed down after the 7 th day in the ones stored at $+30^{\circ} \mathrm{C}$;

- With the increase of temperature, the samples gained strength faster;
- Increasing the temperature reduced the Unconfined Compressive Strength (UCS) values of grouted specimens;

- The permeability values of the grouted samples decreased with time. This decrease slowed down after the 28th day;

- Increasing the temperature decreased the permeability values.

\section{References}

1. Karol, R.H. "Chemical grouts", In Chemical Grouting and Soil Stabilization, 3rd Edn., pp. 122-148, Marcel Dekker, New Brunswick, USA (2003).

2. Anagnostopoulos, C.A., Papaliangas, T., Manolopoulou, S., and Dimopoulos, T. "Physical and mechanical properties of chemically grouted sand", Tunnelling and Underground Space Technology, 26(6), pp. 718724 (2011).

3. Salehzadeh, H., Hassanlourad, M., and Shahnazari, H. "Shear behavior of chemically grouted carbonate sands", International Journal of Geotechnical Engineering, 6(4), pp. 445-454 (2012).

4. Tian, D., Shi, H.Y., and Fu, E.J. "Study on chemical grout permeation mechanism based on experiment of mud and sand medium", Advanced Materials Research, 608, pp. 1809-1813 (2013).

5. Raman, K.V., Dayakar, P., and Raju, K.V.B. "Study on permeation grouting with cement and chebulic myrobalan grout in sandy soils", International Journal of Innovative Research in Science, Engineering and Technology, 4(6), pp. 4448-4456 (2015). 
6. Rahman, M., Hakansson, U., and Wiklund, J. "Inline rheological measurements of cement grouts: effects of water/cement ratio and hydration", Tunnelling and Underground Space Technology., 45, pp. 34-42 (2015).

7. Hashimoto, K., Nishihara, S., Oji, S., Kanazawa, T., Nishie, S., Seko, I., Hyodo, T., and Tsukamoto, Y. "Field testing of permeation grouting using microfine cement", Ground Improvement, 169(2), pp. 134-142 (2016).

8. Faramarzi, L., Rasti, A., and Abtahi, S.M. "An experimental study of the effect of cement and chemical grouting on the improvement of the mechanical and hydraulic properties of alluvial formations", Construction and Building Materials, 126, pp. 32-43 (2016).

9. Hoang, N.C, Bui, D.T., and Wei, L.K. "Groutability estimation of grouting processes with cement grouts using differential flower pollination optimized support vector machine", Applied Soft Computing, 45, pp. 173186 (2016).

10. Mollamahmutoglu, M., Avci, E., Tomac, S.K., and Kose, D.A. "Performance of novel chemical grout in treating sands", Journal of Materials in Civil Engineering, 29(10), pp. 1-12 (2017).

11. Goodman, L.J. and Karol, R.H. "Grouting", In Theory and Practice of Foundation Engineering, 1st Edn., pp. 5-384, Collier Macmillan Ltd, New York, USA (1968).

12. Committee on Grouting "Preliminary glossary of terms related to grouting", J. Geotech. Eng. Div. ASCE, 131, pp. 803-805 (1980).

13. U.S. Department of the Interior, Policy Statement for Grouting, 1st Edn., pp. 3-65, Bureau of Reclamation, Denver, Colorado, USA (1984).

14. EM 1110-3500 "Chemical grout materials", In Chemical Grouting, 1st Edn., pp. 1-10, US Army Corps of Engineers, Washington DC, USA (1995).

15. Anagnostopoulos, C.A. "Laboratory study of an injected granular soil with polymer grouts", Tunnelling and Underground Space Technology, 20, pp. 525-533 (2005).

16. Clifton, W. "Chemical grouts for potential use in bureau of reclamation projects", 1st Edn., pp. 1-48, Dept. of the Interior-Bureau of Reclamation, Denver, USA (1986).

17. Ata, A. and Vipulanandan, C. "Cohesive and adhesive properties of silicate grout on grouted-sand behavior", J. Geotech. Geoenviron. Eng., 124, pp. 38-44 (1998).

18. Hassanlourad, M., Salehzadeh, H., and Shahnazari, H. "Undrained triaxial shear behavior of grouted carbonate sands", International Journal of Civil Engineering, 9, pp. 307-314 (2011).

19. Larionova, N.A., Samarin, E.N., Voronkevich, S.D., and Abramova, T.T. "Chemical grouting of subsidence loess by sodium silicate solutions with low weight ratio", Proceedings of the Fourth International Confer- ence on Grouting and Deep Mixing, 4, New Orleans, Louisiana, United States, pp. 1968-1971 (2012).

20. Porcino, D., Marcianò, V., and Granata, R. "Dynamic properties of sodium silicate-cement grouted sand", Canadian Geotechnical Journal, 49, pp. 1117-1133 (2012).

21. Phan, T.A.V. "Application of sodium silicate-cement grout to enhance the liquefaction resistance and dynamic properties of sandy soil", International Journal of Advanced Structures and Geotechnical Engineering, 3(4), pp. 375-384 (2014).

22. Hsiao1, D.H., Phan, T.A.V., and Jhong, H.C. "Dynamic properties of sodium silicate cement grouted sand", Electronic Journal of Geotechnical Engineering, 19, pp. 17739-17757 (2014).

23. Guyer, J.P. "Chemical grout materials", In An Introduction to Chemicals for Grouting of Soils, 1sth Edn., pp. 8-30, Continuing Education and Development, New York, USA (2015).

24. Porcino, D., Ghionna, V.N., Granata, R., and Marcianò, V. "Laboratory determination of mechanical and hydraulic properties of chemically grouted sands", Geomechanics and Geoengineering, 11, pp. 164-175 (2015).

25. ASTM D2487-11, Standard Practice for Classification of Soils for Engineering Purposes (Unified Soil Classification System), Annual Book of ASTM Standards, American Society for Testing and Materials, West Conshohocken, pp. 1-12 (2011).

26. ASTM D854-02, Standard Test Method for Specific Gravity of Soil Solids by Water Pycnometer, Annual Book of ASTM Standards, American Society for Testing and Materials, West Conshohocken, pp. 1-7 (2002).

27. ASTM D4253-00, Standard Test Method for Maximum Index Density and Unit Weight of Soils Using a Vibratory Table, Annual Book of ASTM Standards, American Society for Testing and Materials, West Conshohocken, pp. 1-14 (2000).

28. ASTM D4254-00, Standards Test Methods for Minimum Index Density and Unit Weight of Soils and Calculation of Relative Density, Annual Book of ASTM Standards, American Society for Testing and Materials, West Conshohocken, pp. 1-9 (2000).

29. Mollamahmutoğlu, M. and Avcı, E. "Effectiveness of microfine portland cement grouting on the strength and permeability of medium to fine sands", Periodica Politechnica Civil Engineering, 59, pp. 319-326 (2015).

30. Haussman, M.R. "Modification at depth by grouting", In Engineering Principles of Ground Modification, 1st Edn., pp. 346-632, Mc Graw Hill, New York, USA (1990).

31. Verfel, J., Rock Grouting and Diagraphragm Wall Construction, 1st Edn., pp. 5-262, Elsevier, Praque, Czech Republic (1989).

32. ASTM D2196-15, Standard Test Methods for Rheological Properties of Non-Newtonian Materials by Rotational Viscometer, Annual Book of ASTM Standards, 
American Society for Testing and Materials, West Conshohocken, pp. 1-5 (2015).

33. Mollamahmutoglu, M., Yilmaz, Y., and Kutlu, I. "Grouting performance of microfine cement and silica fume mix into sands", Journal ASTM International, 4, pp. 1-7 (2007).

34. ASTM D4219-08, Standard Test Method for Unconfined Compressive Strength Index of Chemical- Grouted Soils, Annual Book of ASTM Standards, American Society for Testing and Materials, West Conshohocken, pp. 1-3 (2008).

35. ASTM D2434-68, Standard Test Method for Permeability of Granular Soils (Constant Head), Annual Book of ASTM Standards, American Society for Testing and Materials, West Conshohocken, pp. 1-5 (2006).

36. ASTM D5856-15, Standard Test Method for Measurement of Hydraulic Conductivity of Porous Material Using a Rigid-Wall, Compaction-Mold Permeameter, Annual Book of ASTM Standards, American Society for Testing and Materials, West Conshohocken, pp. 19 (2015).

37. Gonzalez, H.A. and Vipulanandan, C., Behavior of a Sodium Silicate Grouted Sand, Geo-Denver 2007, 1, Denver, Colorado, United States, pp. 1-10 (2007).

38. Thakur, L.S., Shah, L.S., Murali R., Shah, D.L., and Murthy, C.N. "Design and characteristics of polymer based sodium silicate grout", Indian Geotechnical Conference, 1, Guntur, India, pp. 388-392 (2009).

39. Bodocsi, A. and Bowers, M.T. "Permeability of acrylate, urethane, and silicate grouted sands with chemicals", Journal of Geotechnical Engineering, 117, pp. 1227-1244 (1991).

40. Krizek, R. and Spino, M. "Spatial and directional variations in engineering properties of an in situ silicategrouted sand", Proceedings, Advances in Grouting and Ground Modification Conference, 1, Denver, USA, pp. 139-154 (2000).

41. Mollamahmutoglu, M. and Avci, E. "Syneresis effect on the permeability of chemically grouted sand", Quarterly Journal of Engineering Geology and Hydrogeology, 49, pp. 327-335 (2016).

\section{Biography}

Eyubhan Avci is an Assistant Professor at the Department of Civil Engineering, Bursa Technical University (Bursa, Turkey). He received his BS from Dokuz Eylül University (İzmir, Turkey) and obtained MSc and PhD from Gazi University (Ankara, Turkey). His research interests include ground improvement, slope stability, and foundation engineering. 